\title{
NASÎHAT-NÂME TÜRÜNDE BİR ESER: KASÎDE-İ ŞİNÂSİ
}

\section{A WORK IN THE NASÎHAT-NÂME TYPE: KASÎDE-İ ŞINÂิSI}

\section{Fırat SEVINÇ * Öz}

Türk edebiyatında birçok nasîhat-nâme bulunmaktadır. Bunlardan bazıları müstakil tarzda eserlerdir. Bazlları da manzum veya mensur eserlerin içerisinde yer alır. Bugüne kadar her iki manada birçok nasîhat-nâme tespit edilmiş ve Latin harflerine aktarılmıştır. Ahlaki, dinî ve didaktik mesajlar içeren manzum nasîhatnâmelerde kullanılan nazım şekilleri genellikle mesnevi, kaside ve terci-i benttir. Bunlardan en çok tercih edileni mesnevidir. Diğer nazım şekilleriyle yazılan nasîhat-nâmelere ender rastlanmaktadır. Bu çalışmada ele alınan nasîhat-nâme kaside nazım şekliyle yazılmıştır. Kasidenin aruz kalıbı (mefãc īlün / mefäcīlün /

Anahtar Kelimeler Şinâsi, Nasîhat-nâme, Kaside-i Şinâsi, şiir, İman Manzumesi

Keywords

Şinâsi, Nasîhat-nâme, Kaside-i Şinâsi, poetry, İman Manzumesi

* Dr. Öğr. Üyesi, Gaziantep İslam Bilim ve Teknoloji Üniversitesi İslami İlimler Fakültesi İslam Tarihi ve Sanatları Bölümü firatsevinc13@gmail.com ORCID: 0000-0003-3618-5169 Gaziantep/TÜRKIYE

Gönderim Tarihi: 10/12/2020 Kabul Tarihi: $\quad$ 08/06/2021 mefấīlün / mefãcīlün) şeklindedir. Eser 274 beyitten oluşmaktadır. 17. Yüzyllda yazılan eserde eski Anadolu Türkçesinin dil özellikleri görülmektedir. Eser baştan sona kadar dinî, tasavoufi ve ahlaki nasihatlar içermektedir. Kasîde-i Şinâsi başlıklı nasîhat-nâme Diyanet İ̧sleri Başkanlı̆̆ı'nın Yazma Eserler Kütüphanesi'nde İman Manzumesi adl eserin baş kısminda bulunmaktadır. Nasîhat-nâme Arap harflerinden Latin harflerine aktarldıktan sonra eserin dil, şekil ve muhteva özellikleri hakkında bilgi verilmiştir. Eserden hareketle Şinâsi'nin düşünceleriyle ilgili bazı tespitler yapılmıştır. Bu çalışmadaki amacımız Kasîde-i Şinâsi başlıklı nasîhat-nâmeyi tanıtmaktır.

\section{Abstract}

There are many nasîhat-nâmes in Turkish literature. Some of these are private works. Some of them take place in verse and prose works. To date, many nasîhatnâmes have been identified in both terms and have been translated to Latin letters. The verse forms used in verse Nasihat-nâmes containing moral, religious and didactic messages are generally mesnevi, eulogy and terci-i bent. The most preferred of these is the mesnevi. Nasîhat-nâmes written in other verse forms are rare. The nasîhat-nâme named Kasîde-i Şinâsi was written in eulogy form. The

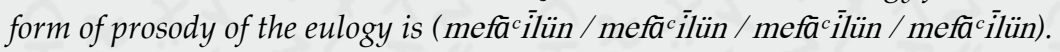
The work is 274 couplets. The language of the ancient Anatolian Turkish can be seen. The work was written in the 17 th century. The work contains religious, mystical and moral advice.

The advice-nâme titled Kasîde-i Şinasi can be found at the beginning of the work titled Iman Manzumesi in the Manuscripts Library of the Presidency of Religious Affairs. After the nasîhat-nâme was transferred from Arabic letters to Latin letters, information was given about the language, form and content features of the work. Based on the work, some determinations were made about Şinasi's thoughts. Our aim in this study is to introduce the advice-nâme titled Kasîde-i Şinasi. 


\section{Gíriş}

Nasihat nush kökünden türeyen bir kelimedir. Nush "saf, halis olmak, kötülük ve bozukluktan uzak bulunmak; iyi niyet sahibi olmak ve başkasının iyiliğini istemek" (Çağrıc1, 2006, C. 32, s. 408) gibi anlamlara gelir. Nasihat kelimesi süreç içerisinde name kelimesiyle birleşerek edebî bir tür olan nasîhat-nâmelere isim olmuştur. Nasîhatnâmeler öğüt ya da ders vermek amacıyla kaleme alınan manzum, mensur ya da manzum-mensur karışık eserlerdir. Arapça-Farsça birleşik bir isim olan nasîhatnâmenin Farsçadaki karşılığı pend-nâmedir.

Ahlaki, dinî, tasavvufi, ilmî ve sosyal mesajlar içeren nasîhat-nâmelerde dinin emir ve yasaklarına, gelenek ve göreneklere, yapılması ve yapılmaması gereken davranışlara yer verilir. Bunlar anlatılırken vecizelerden, atasözlerinden, çeşitli hikâyelerden, ayet ve hadislerden yararlanilır (Pala, 2006, C. 32, s. 409).

Türk edebiyatında nasîhat-nâme tarzı eserlerin geçmişi Orhun Anıtları'na kadar dayanmaktadır. Orhun Anıtları'nda Türk milletine yol gösterici mesajlar verilir ve Türklerin dikkat etmesi gereken hususlar nasihat şeklinde belirtilir. Yazılan ilk siyâsetnâmelerde nasîhat-nâmelerin içerik özelliklerine rastlanır. Bu manada siyâset-nâmeler nasihat-nâme türü eserlerin bir üstü olarak kabul edilir. Dönemin önemli bir siyâsetnâmesi olan Kutadgu Bilig her ne kadar temelde devlet adamlarına iyi bir yönetici olmanın inceliklerini anlatmak amacıyla yazılsa da bütün insanlara toplum hayatında nasıl yaşamaları gerektiğini ve örnek insan olmalarını öğütlemesinden (Yiğit, 2015, s. 105) dolayı nasîhat-nâme türünün özelliklerini taşır. Ayrıca Atabetü'l Hakâyık ve Divân-ı Hikmet, içerisinde manzum nasihatler barındıran ilk eserler olmalarından dolayı nasîhat-nâme türünün özelliklerini yansitır.

Nasîhat-nâmenin Anadolu'da müstakil bir tür olarak ortaya çıkışı Yunus Emre'nin Risâletü'n-Nushiyye'siyle (Tatc1, 2005) başlar. Daha sonra 14. yüzyılda Ahmet Fakih'in Çarh-nâme'si (Mansuroğlu, 1956), Hoca Mesud'un Ferheng-nâme'si (Çelebi ve Rıfat, 1340/1922), Âşık Paşa'nın Garib-nâme'si (Yavuz, 2000), Süleyman adlı şairin Nasîhatnâme'si (Çelebioğlu, 1999, s. 94), Mürîdî'nin Pend-i Ricâl'i (Kılıç, 2005); 15. yüzyılda Refîi'nin Beşâret-nâme'si (Yiğit, 1986), Ahmed-i Dâî'nin Vasiyyet-i Nuşirevân-ı Âdil Be Pusereş'i (Yeniterzi, 2006), Arif'in Mürşidü'l-Ubbâd'1 (Tınç, 1996), Saruhanlı Gülşenî'nin Dil-Güşấ'si (Gülşenî, yz. 1403), Şeyh İbrahim Gülşenî'nin Pend-nâme'si (Gülşenî, yz. 1042/3, 17b-20a), Yetîmî'nin İbret-nâme'si (Yetîmî, yz. 588/1), Şeyh Eşref'in Nasîhatnâme'si (Köprülü, 1980); 16. yüzyılda Za'îfî'nin Kitâb-ı Sabru'l-Mesâyib'i (Yalçınkaya, 2019), Hatâyî'nin Nasîhat-nâme'si (Arslanoğlu, 1992), Nevâlî̀nin Çeşme-i Hayat'1 (Kurnaz, 2018), Şemsî'nin Deh Murg'u (Aksoy, 1998; Kaya, 1997), Cemâlî'nin Nasîhatnâme'si (Cemâlî, yz. 593/5, 62a-66b), Hüseynî'nin Câmiü'n-Nasâyih'i (Hüseynî, yz. 661/19), Hakkânî'nin Cevâhir'i (Kurt, 2020), Askerî'nin Pend-nâme'si (Askerî, yz. 62/2), Cemâl'ın Kasîde-i Nasîha-i Muhrika's1 (Kaplan, 1993a), Güvâhî'nin Pend-nâme'si (Hengirmen, 1983), Hizrî'nin Âb-ı Hayât'ı (Belen, 1997), Zaîfí'nin Bustân-ı Nesâyih'i (Zâifî, yz. 822/2), Gubârî'nin Pend-i Gubârî́s si (Kaplan, 1993b), Nidâî'nin Nasîhat-nâme'si (Kaplan, 1993c), Meşâmî'nin Pend-nâme-i Meşâmî'si (Kaplan, 1993d), Keşfî'nin Te'dibnâme'si (Levend, 1963), Emîrî́nin Gülşen-i Ebrâr'1 (Emîrî, yz. 2584/1), Sinan Paşa'nın Ma'ârifnâme'si (Çelik, 2018); 17. yüzyılda İlmî'nin Pâdişâha Nasîhat Yollu Manzûme'si 
(İlmî, yz. 968, 125a), Mantıkî'nin Nasîhatnâme'si (Çınar, 2014), Bursalı Mehmed Tahir'in Edeb-nâme'si (Tahir, 1325), Üveysî'nin Nasîhat Yollu Manzûme'si (Üveysî, yz. 4635), Ali b. Mahmud'un Umûr-ı Ahvâl-i Sefer'i (Ay, 2018), Rızaî'nin Nazmu'l-Ulûm'u (Rızaî, yz. 2433, 96b-109a), Fazlî'nin Pend-nâme-i Fazlî́si (Fazlî, yz. 245/2), Sar1 Abdullah Efendi'nin Nasîhatül-Mülûk Terğî̉ün Li-Hüsni's-Sülûk'u (Bütün, 2019), Nâbî'nin Hayriyye'si (Kaplan, 1990), Fasîh Ahmed Dede'nin Behişt-Âbâd'1 (Sevindik, 2010), Kâtip Ali Efendi'nin Pend-nâme'si (Benli, 2020), Kâdirî Muhyiddîn'in Nasîhat-nâme'si (Kazancıoğlu, 2019); 18. yüzyılda Mevlânâ Muhammed Emîn Müftîzâde'nin Levhnâme'si (Yiğiterol, 2019), Sâfî'nin Gülşen-i Pend'i (Sâfî, yz. 8471), Mürşid Efendi'nin Pend-i Mürşidî'si (Mürşid Efendi, yz. 784), Rusçuklu Zarîfî́nin Pend-nâme'si (Arslan, 1994); 19. yüzyılda Harputlu Ömer Naîmî'nin Manzûme-i Naîmîyye'si (Ceyhan, 2020), Sünbül-zâde Vehbî'nin Lutfiyye'si (Beyzadeoğlu, 1996), Sıdkî'nin Nasîhatnâme-i Sıdkî'si (Koşik, 2012), Vak'anüvis Es'ad Efendi'nin Pend-nâme-i Vak'anüvis Es'ad Efendi'si (Kaplan, 1997), Halil Efendi'nin Lübbü'n-Nesâyıh'1 (İslamoğlu, 2012), Hüznî'nin Nasîhatnâme'si (Oğuz, 1990), Hüsrevzâde Ömer Sabrî'nin Nasîhat-nâme'si (Söylemez, 2020) ve 20. yüzyılın başlarında kaleme alındığı belirtilen ancak müellifi tespit edilemeyen Maksûd-ı Nasîhat (Ak, 2018) nasîhat-nâme türünde yazılan eserlerden bazıları olarak görülmektedir.

Kasîde-i Şinâsi' nin yazıldığı 17. yüzyılda Osmanlı Devleti'nde askerî, sosyal ve ekonomik sebeplerden dolayı birçok karışıklık yaşanmıştır. 16. ve 17. yüzyılda uzun süren savaşlar bütçeye ağır yükler getirmiş, asker arasındaki disiplinsizlikler zamanla devlete isyana dönüşmüştür. II. Osman'ın 1622'de öldürülmesi ve akıl sorunları olan I. Mustafa'nın tahta geçirilmesi bu olumsuz durumu daha da körüklemiştir. 1623 yılında daha çocuk yaşta tahta geçen IV. Murat zaman içerisinde devlet iradesini tekrar göstermeye başlamış fakat bu durum onun ölümüyle bozulmaya uğramıştır.

16. yüzyıldan itibaren Osmanlı Devleti'nde yaşanmaya başlananan sıkıntılar siyâset-nâme ve nasîhat-nâme türünde birçok eserin kaleme alınmasına (Kazancıŏ̆lu, 2019, s. 35) zemin hazırlamıştır. Yazılan siyâset-nâmelerde devlet idarecilerine yol gösterilmiş ve sağlam temellere dayalı bir devletin hangi esaslara bağlı kalması gerektiği belirtilmiştir. Nasîhat-nâmeler ise toplumdaki düzensizliklerden dolayı sıkıntılara düşen halkı manen ayakta tutmak ve İslam dinine olan bağlılığı güçlü kılmak için yazılmış, bu eserlerde daha çok dinî, ahlaki ve tasavvufi nasihatler içeren sözlere yer verilmiştir. 17. yüzyılda yazılmış olan Kasîde-i Şinâsi'nin de böyle bir amaçla yazıldı̆̆ tahmin edilmektedir.

Şinâsi, nasîhat-nâmesinin 129. beytinde âlemin dinî anlamdaki hâlini hikâye ettiğini belirterek toplumda olumsuz şartların söz konusu olduğunu sezdirir. Eserin yazıldığı asırdaki şartlar düşünüldüğünde bu şartların insanların ruh hâllerinde sıkıntılar meydana getirdiği söylenebilir. Şinâsi'nin, bu eseri insanların isyana ve günaha düşmesini engellemek, dolaylı olarak devlet otoritesine katkıda bulunmak, insanların manevi refahını sağlamak ve İslam'a olan bağlılığı sağlamlaştırmak için kaleme aldığ 1 ifade edilebilir.

Kasîde-i Şinâsi Diyanet İşleri Başkanlığı'na ait elektronik sayfada Yazma Eserler Kütüphanesi'ndeki İman Manzumesi adlı eserin içinde yer almaktadır. İman 
Manzumesi'yle ilgili olarak söz konusu kurumun elektronik sayfasında şu bilgiler yer almaktadır: Dil kodu Osmanlı Türkçesidir. Dewey sistemine göre yer numarası 810.2/23 şeklindedir. Varak sayısı 27a-29a olarak belirtilir. Yazı türü nesih olup satır sayısı 17'dir. Kâğıt, nohudi renkte filigranlı kâğıttır. Mürekkep rengi siyahtır. Eserin kondisyonuyla ilgili olarak eserin şirazesinin dağıldığı, formalarının cildinden ayrıldığı bilgisi verilir. Ayrıca eserin çoğu varağında su lekelerinden dolayı kararmalar olduğu ifade edilir. Rakabe kaydı bilgisinin mevcut olduğu yazılıdır.

Iman Manzumesi adlı eserin müellif ve müstensihi hakkında bir bilgi verilmemektedir. Eser toplam seksen varaktan oluşmaktadır. Eserde fıkıhla ilgili konulardan bahsedilir. Kasîde-i Şinâsi başlıklı bölümden sonra sirasıyla "Hâzâ Risâle-i Kadı-zâde Rahmetullahi Aleyh, Risâle-i Kadı-zâde Efendi Rahmetullahi Aleyh, Hâzâ Esmâü'lHüsnâ ve Hâzâ Risâle-i Ehlü's-Sünnet ve'l-Cemâat" başlıklı dört bölüm daha mevcuttur. Eser içerik bakımından karşılaştırıldığında dört bölümdeki bilgilerin benzer olduğu, bundan dolayı dört bölümün de aynı kişi tarafından yazıldığı sonucuna varılır. Bu bölümlerde bazı manzum kısımlar vardır. Eserin konuyla bağlantılı olmayan kısımlarında hicri olarak 1123 ve 1124 tarihleri görülmektedir. Bu tarihler eserin telif veya istinsah tarihiyle ilgili değildir. Son sayfada “oğlum Hüseyin'in dünyaya geldiği tarihtir (1223)" şeklinde sonradan yazıldığı belli olan bir not düşülmüştür. Kitabın tamamlandığı kısımda, "temme'l-kitâb" ifadesinden hemen sonra "sene 1063" tarihi verilmektedir. Miladi 1652/1653'e denk gelen bu tarihin eserin istinsah tarihi olduğu anlaşılmaktadır.

İman Maunzumesi'nin müellifiyle ilgili herhangi bir isim geçmemektedir. Ancak eserdeki iki bölüm başlığında yazılı olan "Kadızâde" lakabından hareketle eserin 17. yüzyılda yaşamış "Kadızâde" olarak tanınan bir şahsa ait olduğu açıktır. "Risâle-i Kadızâde Efendi Rahmetullahi Aleyh" başlıklı kısımda yer alan "Baña bu devlet iki cihānda pes durur hemān / Hem dahi ki āsitān-ı nakş̧bende intisābım var benim" beytinden Kadızâde lakaplı şahsın Nakşibendi tarikatına mensup olduğu anlaşılmaktadır. 17. Yüzyılda Kadızâde lakabıyla anılan birçok âlim mevcuttur. Bunlardan biri de Kadızâde Mehmed Efendi'dir (ö. 1635). Ciddi bir eğitim alan Kadıâde Mehmed Efendi kitap ve risaleler yazmıştır. Bu eserlerinde isim kullanmayı tercih etmemiştir. Ona nispet edilen eser sayısı yedi ile on iki arasında değişmektedir (Özkan, 2016, s. 558). Elimizdeki eserde yer alan bilgilerin içeriği ile Kadıâde Mehmed Efendi'nin diğer eserlerindeki bilgilerin içeriği birbirine benzemektedir. Ayrıca Kadızâde Mehmed Efendi, Risâle-i Müdâfa'a adlı eserinde Yalova'da ikamet eden Muhammed Nakşîbendî adında bir şeyhle dost olduğunu ve ona biat ettiğini belirtmekte, onun sayesinde birçok Nakşi şeyhiyle tanıştı̆̆ını ifade etmektedir (Durmuş, 2020, s. 327). Bu bilgiyle beyitteki Nakşilik bilgisi de örtüşmektedir.

Iman Manzumesi'nin baş tarafında yer alan Kasîde-i Şinâsi başlıklı nasîhat-nâmede mahlas beyti bulunmamaktadır. Ancak başlıkta kullanılan Şinâsi isminden hareketle bu nasîhat-nâmenin Şinâsi mahlaslı bir şahıs tarafından yazıldığına kanaat getirebiliyoruz. Eserin istinsah tarihi göz önüne alındığında kaynaklarda 17. yüzyılda Şinâsi mahlasını kullanan bazı şairlere rastlanmaktadır. Bilinenler arasında Ruznâmeci-zâde Şinâsi (ö. 1702/1703) ve Abdurrahman Şinâsi Çelebi (ö. 1675) isimleri 
mevcuttur. Ruznâmeci-zâde Şinâsi'nin bilinen tek eseri divanıdır. Divan üzerine 1999 ve 2000 yıllarında yapılmış iki adet yüksek lisans tezi mevcuttur (Harmancı, 1999; Akpınar, 2000). Bu çalışmada ele aldığımız nasîhat-nâme tezlerde bulunmamakta ve nasîhat-nâmeden de söz edilmemektedir. Abdurrahman Şinâsi Çelebi'yle ilgili herhangi bir çalışma tespit edilememiştir. Babinger (1982, s. 196), Şinâsi Mehmet Ağa isimli bir şahsın Nüzhetü'l Ahbâr fi-İcmâl Sefer-i Zigetvar adında bir eserinin olduğunu söyler. Harmancı'ya göre (1999, s. XXXVII) bu şahıs Abdurrahman Şinâsi Çelebi'dir. Sicill-i Osmanî'de Abdurrahman Şinâsi Çelebi'nin ölüm tarihi miladi 1675 olarak gösterilmektedir (Akbayar, 1996, s. 1601). Abdurrahman Şinâsi Çelebi'nin müderrislik, kadılık yaptığı ve Rumelili olduğu (Altun, 1997, s. 39; Selçuk, 2020) belirtilir. Şinâsi'nin, nasîhat-nâmedeki Arapça kullanımlara olan hâkimiyeti onun kadılık yapacak kadar bir Arapça eğitimi aldığını gösterir. Rumelili olmasından dolayı Kadıâde Mehmed Efendi'nin yaşamış olduğu İstanbul'daki dinî ve kültürel hayata da yakındır. Ayrıca nasîhat-nâmedeki "O şehriñ vay hạ̄line kim olasin anda sen ḥākim / Yıkılmasa cacebdir o hilāf-ile hilāfetden (262. Beyit) ile Ķılursın illere vacz u nașihhat çıkuben kürse / cAceb budur ki tutmazsin sen evvel ol nașiḩatden (263. beyit)" şeklindeki kendisini işaret ederek nasihatte bulunduğu beyitler göz önüne alındığında, "bir şehrin hâkimi olmak" ve "kürsüye çıkıp vaaz vermek" ifadeleriyle Şinâsi'nin kadılık mesleğini icra ettiğine dair izler olduğu düşünülmektedir. Ayrıca Abdurrahman Şinâsi Çelebi'nin ölüm tarihi ile nüshanın istinsah tarihinin yakınlığı, Iman Manzumesi'nin müstensihinin Abdurrahman Şinâsi Çelebi olabileceği ihtimalini güçlü kılmaktadır.

\section{ŞİNÂSİ HAKKINDA BAZI DEĞERLENDİRMELER}

Tezkirelerde çalışmamızdaki nasîhat-nâmenin yazarı olduğu düşünülen Abdurrahman Şinâsi Çelebi hakkındaki bilgiler sınırlıdır. Rumelili olduğu, müderrislik ve kadılık yaptığı, ilim sahibi ve yumuşak başlı bir insan olduğuna (Selçuk, 2020) dair bilgiler mevcuttur. Bundan dolayı şairle ilgili değerlendirmelerde beyitler üzerinden hareket edilecektir.

Şinâsi İslam dininin kurallarına samimiyetle sıkı sıkıya bağlılık gösterilmesi gerektiğini düşünmektedir. Kişinin dünyada gerçekleştirdiği fiillerinden dolayı sorumlu olduğunu ve günü geldiğinde bunlarla ilgili sorgulanacağını söyler. Kişinin, yaptığı fiilerin yanlışlığını bile bile bu fiilleri yapmaktan sakınmamasını ağır bir suç olarak görür. Müminlerin fiil, konuşma ve inanç durumlarının niteliğinden dolayı bazen münafıklığa düşebileceğini belirtir. Şinâsi inanmış insanların bu durumunu ifade ederek titiz bir yönünün olduğunu ortaya koyar:

Eger șoru ḥesāb olmaz dir-iseñ kāfir olursın

Ger olur dir-iseñ n'içün șaḳınmazsın cināyetden (24. Beyit)

Bilinmişdir bugün bunda ḳamu mü’min münāfiḳ hep

Kimi ef āl aḳvāl u kimi dīn ü diyānetden (32. Beyit)

Şinâsi, nasihat-nâmesinde seslenirken aslında kendisine seslenir. Bu da onun mütevazı olduğunu gösterir. Mütevazılığı ve kaynaklardaki yumuşak başlı biri olduğu bilgisi örtüşür. İcra ettiği meslekten dolayı beyitlerde bazen vaaz verme havasının 
oluştuğu ve ses tonunun yükseldiği görülür. Gaflette olanlar bir an önce gafletten uyanmalıdır. İnsan Allah tarafından kendisine emanet edilenleri düşünerek kendini hesaba çekmeli ve eksiklerini görmelidir:

Nice uyursın ey gāfil uyan bu h ȟāb-1 gafletden

Ne nokṣān eylemişsin țur ḥesāb it gör emānetden (1. Beyit)

Şinâsi şeriatın kurallarına bağlı bir insandır. İslam'ın gereklerini yerine getirmeyen kişilerin şehadetlerinin düşeceği ifadesini dile getirir. Şinâsi'ye göre İslam inancı yerine getirilecek davranışlar noktasında günlük hayata yansıtılmalı, İslam'ın değer ve ibadetlerine göre bir hayat yaşanmalıdır. Namaz, oruç, taharet ve tevhit gibi İslami unsurların ancak bu şekilde anlam kazanacağını düşünür. Namazın çok önemli olduğunu belirterek düzenli bir şekilde eda edilmesi gerektiğini ifade eder:

Eger dirseñ şehādetdir hemān aṣl olan İslāma

Kavil kim uymaya ficle düşer kişi şehādetden (9. Beyit)

Tamām olur mı ṣanursın hemān tevhịid ile İslām

Bile olmayıcaḳ șavm u șalat-ile țahāretden (10. Beyit)

Saña emr oldı Ḩālıḳdan ki beş vaḳtde namāz eyle

Beyān oldı dahi vaḳti ezāan-ile iḳāmetden (11. Beyit)

Şeriat insanlar için koruyucu bir cevşen, tarikat ise giyilmesi gereken bir cübbedir. Şeriat ve tarikat insanları dünya hayatının çirkinliklerinden korur. Tarikatın çeşitli anlamları vardır. Birincisi Allah'a ulaşmak için izlenilen yoldur. İkincisi ise belli bir İslami düşünce etrafında teşekkül eden topluluktur. Beyitte ikinci mananın kastedildiği düşünülürse Şinâsi'nin bir tarikata mensup olduğu sonucu çıkarılabilir. İnsanı dünya hayatının kötülüklerinden koruyan diğer unsurlar Allah'a itaat ve sadakattir. İtaat savunucu bir kılıç, sadakat ise bir hazinedir. İbadet hâlinde olup kalp gözünün açık tutulması gerekir. İnsana kendini kötülüklerden koruması için yetki ve irade verilmiştir. İnsan yetki ve iradesini ecel vakti gelinceye kadar iyi yolda kalmak amacıyla kullanmalıdır:

Şerīiat cevşenin giyin țariḳat cübbesin pāyın

Ki tā kār itmeye düşmān saña işbu hașāṣetdan (184. Beyit)

İtācat ḳılıcın daḳın ṣadāḳat gencini șaḳın

cíbādet birle ol yaḳın berī olma baṣāretden (185. Beyit)

Ṣalāhiyyet silāḥınıñ ḳamusın idegör ḥāżır

Dahi denilmeden gel git saña emr ü irādetden (187. Beyit)

Şinâsi sorgulayıcı bir özelliğe sahiptir. Tefekküre önem verir. Allah'a kul olma bilinciyle hareket etmeye çalışır. İnsanoğlunun kendini sorgulaması ve dünyaya geliş nedenini araştırması gerekir. İnsanın mensup olduğu ırkın ve milletin, nereli olduğunun, mal varlığının ve toplum içindeki statüsünün bir önemi yoktur. Önemli olan dünyaya gönderiliş amaçlarına göre hareket edip etmediğidir. Şinâsi bu şekilde 
varlığını sorgulayan ve iç dünyasında cevaplar arayan bir insan profili ortaya koyar. Tefekküre yönelerek varoluşa uygun hareket tarzını bulma çabası içerisindedir:

Ya sen kimsin ne iş içün seni gönderdiler bunda

Nice hidmet edā itdiñ cadāvetden șadāḳatden (69. Beyit)

Nedir adiñ ne yerdensin ne milletden urursin dem

Aġa mısın veyāhut ḳul ḩaber vir bir emāretden (70. Beyit)

Ger ag̉asın bu iḳlīmi saña tīmār kim virdi

Ne ḳıldıñ şāh içün hiidmet ne gösterdiñ besāletden (72. Beyit)

\section{NASîHAT-NÂMENIN DILL VE ŞEKIL ÖZELLIKLLERI}

Kasîde-i Şinâsi'nin hemen öncesinde dört bentten oluşan bir murabba bulunmaktadır. Aruzun (mefācìlün/ mefācìlün) kalıbıyla yazılmış olan murabbanın kime ait olduğuyla ilgili bir bilgi mevcut değildir. Murabbanın Şinâsi'ye ya da müstensihe ait olduğu düşünülmektedir. Şinâsi'yle müstensihin aynı kişi olabilme ihtimali de söz konusudur. Murabbayı yazan kişi Allah'a içinde bulunduğu durumu ve pişmanlıklarını ifade ederek Allah'tan af dilemektedir.

Yüregim yaşludır her dem

Aḳar gözüm yaşı dem dem

Bu zahme ol ura merhem

$\mathrm{Ki}$ andandır ḳamu yārem

Eger fażl eyleye Hुālı̣̣

Olurum rahmete lāylk

Ve ger cadl eyleye rāzık

Ṭamuya key seza-vārım

Bu işden ḩāṭırım gam-gīn

Kalurım nāle vü nefrīin

Ki dā'im yazduġım vașfin

Ciger ḳanıyla yazarım

İlāhi șuçumı bildim

Kapuña yalvarı geldim

Mugirem her ne kim ḳıldım

Degil ki ehl-i inkārım

Manzum nasîhat-nâmelerde kullanılan nazım şekli genelde mesnevidir. Çalışmamıza konu olan eserde kaside nazım şekli kullanılmıştır. Kasidede baştan sona kadar nasihat verilmiş olup kasidenin bölümlere ayrılması söz konusu değildir. Nasîhat-nâmede kafiye örgüsünü oluşturan kelimelerin genelde dört heceli Arapça kelimeler olduğu görülmektedir. Bu da şairin aruzun on altı heceli uzun bir kalıbını kullanmasına imkân sağlamaktadır. Kalıptan dolayı beyitlerde kullanılan kelime 
sayısının fazlalığı şairin konuyu daha fazla kelimeyle izah etmesine katkıda bulunmuştur.

Kasîde-i Şinâsi'nin ve içinde bulunduğu Iman Manzumesi'nin başka bir nüshasına rastlanmamıştır. Mevcut nüshanın nasîhat-nâmeyle ilgili kısmı 17 varaktan oluşmaktadır. İlk ve son sayfalar hariç diğer sayfalardaki satır sayısı 17'dir. Eser 274 beyitten oluşmaktadır ve aruzun (mefācīiün / mefācīiün / mefācīiün / mefācīiün) kalıbıyla yazılmıştır. Beyitlerde tam kafiye ve redif kullanılmıştır. Eserde az sayıda mısrada aruz kusuru görülmektedir. Şair bazı kelimelerde okuyuşu kolaylaştırmak ve anlaşılabilirliği sağlamak için kelimeleri harekelendirmiştir. Nasîhat-nâmenin 155'inci beytinin birinci mısrasının yazılı olmadığı, 142. beyitte de mısraların yer değiştirdiği görülmektedir. Her iki durumun da müstensihin o anki dalgınlığından kaynaklandığı düşünülmektedir.

17. yüzyılda yazılan bu nasîhat-nâmede eski Anadolu Türkçesinin kullanımlarına yer verilir. Eserdeki “dürişirdin (6), deyü (7), birle (14), nic'olacaġıñ (16), așș1 (23), ḳaçan (31), ḳamu (32), ḳakı (34), berk (37), habu (40), ḳo (41) imdi (46), bite (59), ḳanden (68), urursın (70), șıyup (73), țaşra (77), uş (80), üzmek (82), uma (84), șog̉an (86), buggday (86), esirger mi (93), yeyni (93), yelersin (104), aldar (114), esriklikden (122), al (126), girü (148), yavlak (164), tizcek (172), yarag (178), yaluñuz (181), işbu (184), yeñdürür (189), țamu (208), şilke (218), uçmaḳ (238), 1ssı (246), üşüp (249), șayru (249), oñmadıḳ (256), ün (257), yu-mak (270), ,rılma (271)" gibi kelimeler bu duruma örnek olarak verilebilir.

Eserde öğreticilik ve faydalı olma amacı güdüldüğü için uyarıcı tarzda bir üslup benimsenmiştir. $\mathrm{Bu}$ anlamda birçok beyitte ikinci tekil şahıs üzerinden seslenmeler görülmektedir. "ādemsin (5), ușanmazdın (6), melcūnsun (12), bileydiñ (16), inanmazsın (20), n'olısarsın (21), șaḳınmazsın (24), ḳorḳmayasın (29), münāfıḳsın (34), şaḳịısın (37), uṣlan (55), ag̉a mısın (70), işitdiñ (128), gaāfilsin (145), uymadıñ (160), ḳurtarıbilürseñ (196), aldandıñ (201), denilendensiñ (245), ḳ1lursın (263)" gibi kelimeler buna örnektir.

Bu nasîhat-nāmede eski Anadolu Türkçesine ait dil ve ses hususiyetleri oldukça fazladır. Aşağıdaki kelimeler bu hususiyetleri barından bazı örneklerdir:

e-i değişimi: $\dot{t}(1)$, didi (4), iden (15), gice (17), benimsidün (39), irişür (123), yıl (126), dir (130), virdi (202).

1 (i) - u (ü) değişimi: ayrusın (12), deñlü (22), țolı (28), bilürsin (80), yanḳu (88), irişür (123), gidüp (150).

ö-e değişimi: eylece (129).

t - d değişimi: işiđir (12), işit điñ (20), țolı (28), țurmaḳla (39), țaşın (135), țaldın (163), țarlığı (169), daḳın (185), țolaşur (233), dükenmez (241), dürlü (135).

ğ - g değişimi: eger (16), meger (19), gögsüñ (95), degil (133), degişdin (164), ögrendin (199), yeg-dürür (211).

k - g değişimi: bıraǵub (31), ḳalmaǵadır (41), yog்-ise (36), aǵmadın (96), iligi (230), țırnaǵııı (231).

k - h değişimi: uyḩu (67), ḳorḩu (37).

p - b değişimi: barmag̉ (231). 
Ses ve hece düşmeleri: neyin (7), ḳoymazsin (25), onlar (46), ne-eylermiş (128), şunlar (137), ne-olur (139), ne-idem (145), șararır (175), oraya (180), bunları (220).

Şahıs ekleri: uyursın (1), bilmen (102), kurtulasız (172), bileydi(266).

Zaman ve kip ekleri: oldı (3), olıcak (15), olaydĩn (17), geçeydĩ̃ (17), olısarsın (21), bulısarsın (21), bilür (65), yog்-idi (153), olmaǵıl (180).

Birleşmiş kelimeler: eżān-ile (11), n(e)'olısarsın (21), ḳılmaz-isen (22), dir-iseñ (24), bugün (25), n(e)'içün (29), çünkim (46), var-ise (53), anıñ-(i)çün (63), uyanıgör (67), Hak-içün (81), biraz (119), n(e)'olduǵm (121), nic(e)'oldug m (124), n(e)'itdi (125), n(e)'eylermiş (128), n(e)'itdünse (171), dönegör (171), idegör (187), kurtarıbilürsen (196).

İşaret sıfatları: şol(13), ol(13).

İşaret zamirleri: anı (12), aña (43), ol(44), ol-dur (84).

Kişi zamirleri: şular (137), andan (180), bular (220).

Bildirme ekleri: buyurmuşdır (13), kuldır (54), alup-durur (117), çoḳ-durur (188).

Seslenme edatları: ey(1), hey(67), vay(59).

Fiilimsiler: gelmeden (18), olası (39), àgmadın (96), düşmedin (96), bulınca (98), geldügiñ (100), irdikde (136), çıłuben (263).

İyelik ekleri: cömriñ (27), kendüyi (115), özini (116), göñlin (119).

İlgi ekleri: anıñ (59), atan(96).

\section{NASÎHAT-NÂMENİN MUHTEVASI}

Manzum nasîhat-nâmelerdeki konular dinî-tasavvufi, genel ahlakla ilgili konular, sosyal hayatla ilgili konular, ilim ve sosyal eleştiri olmak üzere çeşitli başlıklara ayrılır (Kaplan, 2001， s. 133-185). Şinâsi'nin nasihat-nâmesi bu başlıklara göre değerlendirildiğinde dinî-tasavvufi konularla ilgilidir. Ancak genel ahlakla ilgili konuları da içerir. Nasihat-nâmede bir konu düzeni yoktur. Başta ele alınan bazı konuların ortada ya da sonda tekrar ele alındığı görülür. Konuların nerede başlayıp nerede bittiği net değildir.

Şinâsi birinci beyitte "nice uyursun ey gafil" diyerek nasihat-nâmeye uyarıcı bir tarzda giriş yapar. Birinci beyitten altıncı beyte kadar gafletin terkedilmesinden; Allah'ın emir ve yasakları doğrultusunda yaşanması gerektiğinden; Allah tarafından verilen emanetin onun istediği şekilde kullanılmasından; emanetin mahiyetinin değişerek kelam, mal ve nefse dönüştügünden; ibadet etmenin lüzumundan bahseder.

7. ve 17. beyitler arası: $\mathrm{Bu}$ kısımda Müslümanlığa temas edilir. Müslümanların uzak durması gereken hususlar belirtilir. Namazın beş vakit olarak tayin edildiği anlatılır. Cemaatle namazın önemi üzerinde durulur. Hz. Peygamber'in cemaatle namazı telkin ettiği ve cemaatle namaz kılmayanların tehlikelere maruz kalabilecekleri ifade edilir.

18. ve 29. beyitler arası: İnsanoğlunun dünyaya geliş nedeni ibadettir. Nefis ve şeytan insanı ibadetten alıkoymak için uğraşır. İnsan günahlarından dolayı tövbe etmelidir. Tövbe etmezse şefaatten mahrum kalabilir. Doğru şekilde yaşamayan 
insanları kötü bir son beklemektedir. Dünya hayatı şikâyet etmeden şükür içinde yaşanmalıdır.

30. ve 41. beyitler arası: $\mathrm{Bu}$ beyitlerde mümin kişinin özelliklerinden bahsedilir. Müminin hâl ve hareketlerine dikkat etmesi gerekir. Bununla ilgili ayet ve hadislerin olduğu belirtilir. Kötü huylar derhal terkedilerek zikir ve şükürle meşgul olunmalıdır.

42. ve 55. beyitler arası: Dünya geçici bir yurttur. Hz. Peygamber bile herkesten üstün olduğu hâlde dünyada kalıcı olmamıştır. Müslümanlar bu dünyada günahlarından dolayı pişmanlık içerisinde hüzünlü olmalıdır. Günahlarından dolayı gözyaşı dökmelidir. Tevazuyu asla elden bırakmamalıdırlar

56. ve 66. beyitler arası: Allah'ın emir ve yasakları doğrultusunda yaşamayan insanların cehenneme gideceği belirtilir. Cehennemin yakıcılığı anlatılır. Nefis ahireti unutturup insanı kötü yola sevkeder. Nefsin kötülüklerinden korunmak için ölümün hatırda tutulması gerekir.

67. ve 80. beyitler arası: İnsan dünyaya geliş nedeni üzerinde düşünmelidir. Kendini sorgulamalı ve öz benliğinin farkına varmalıdır. Kulluğun gereğini yerine getirerek Allah'ın vermiş olduğu nimetlere şükr etmelidir.

81. ve 89. beyitler arası: Dünya bir ziraat yeridir. İnsanın salih amelleri ziraatten elde edilen ürünler gibidir. İnsan muhakkak suretle ektiğini biçecektir. Gurura kapılarak yaptığı yanlışlar zamanı geldiğinde karşısına çıkacaktır.

90. ve 115. beyitler arası: Müslüman olanlar Allah'ın emirlerine ve resulullahın sünnetine uymalıdır. Mescitten yani ibadetten kaçan kişi kendisinden utanmalıdır. Bir Müslüman başkalarının ayıplarını araştırmamalı, ayıpları saklamasını bilmelidir. Yaratılış sürecinde "mâî ve menî" den yaratıldığını düşünerek gurura kapılmamalıdır. Kendisini yaratan kudretin farkında olmalı ve geçici dünya zevklerine itibar etmemelidir.

116. ve 128. beyitler arası: Şeytan devamlı dünyayı güzel gösterme çabası içerisindedir. Müslüman bunun hayal ve hileden ibaret olduğunu bilmelidir. Bilmezse ölüm gelip kapıyı çaldığında her şey için geç olacaktır.

129. ve 152. beyitler arası: Şinâsi 129. beyitte, bu beyte kadar yazdıklarının sebebini belirtir. Şikâyetlerini ve dünyanın hâlinin hikâyesini ders alınsın diye anlattığını ifade eder. Hz. Peygamber'in söylediklerine kulak verilmelidir. Kabir ehline bakıp ders alınmalı, yapılan her işin dünyada kalacağı ve herkesin dünyadan göçeceği unutulmamalıdir.

Şikāyet eylece itdim hiikāyet ḥāl-i cālemden

Ki hiș̣se ala tā bu hikāyetden şikāyetden (129. Beyit)

153. ve 183. beyitler arası: İnsan tevhit yüküyle yüklüdür. Tevhit ve vahdet insan için birer rehberdir. Zikir ve tespih ruhun gidasıdır. Kötü yola girildiği zaman melekler insanı terk eder. İnsan bu durumdan kurtulmalı ve salih amelle silahlanmalıdır.

184. ve 205. beyitler arası: Şeriat ve tarikat Müslümanlar için koruyucu kalkanlardır. Allah'a itaat ve sadakat şarttır. Ameller salih olmalı fakat amellere 
güvenilip yanlışa düşülmemelidir. Allah'ın insana vermiş olduğu her türlü sermaye insan tarafından tüketilmektedir.

206. ve 226. beyitler arası: İnsan zamanı geldiğinde hesaba çekilecektir. Allah'ın veziri ve naziri yoktur. Allah cehennemi bir zindan olarak yaratmıştır. Cehennemin zindancısı Mâlik'tir. Oradaki azap şiddetlidir. Haram ve helal devamlı hesap edilmektedir. Haram ve helalin kaydedildiği kitap zamanı geldiğinde okunması için sahibinin eline verilecektir.

227. ve 244. beyitler arası: Bu beyitler arasında cennetten bahsedilmektedir. Cennet ehli için orada çeşitli ziyafetler ve saraylar vardır. Oradaki huriler güzel özelliklere sahiptir.

245. ve 259. beyitler arası: İnsan şerefli bir mahluk olarak yaratılmıştır. Allah'ın emir ve yasaklarına aykırı şekilde hareket ettiğinde hayvandan farksız olur. Dünyada rezil olur ve cehenneme maruz kalır.

260. ve 274. beyitler arası: Eserin son beyitlerinde Şinâsi nasihatlerini toparlayarak özet haline getirir. Allah'tan korkulması ve af dilenmesi, fisk ve fesattan uzak durulması gerektiğini belirtir.

Şinâsi vermek istediği mesajlari güçlü kılmak için ayet, hadis, deyim ve atasözlerinden faydalanmıştır. Ayet ve hadislere beyitlerde genelde işaret edilmektedir. Bunun yanında bazı iktibaslar da vardır. Atasözleri ve deyimler genelde aynıdır. Çok az kelime değişikliği mevcuttur.

\section{Ayetler}

“Sen Allah ile beraber başka bir ilâha ibadet etme. O'ndan başka hiçbir ilâh yokdur. O'nun zatından başka her şey yok olacaktır. Hüküm yalnızca O'nundur ve kesinlikle O'na döndürüleceksiniz." (Kur'an-1 Kerim 28: 88) ayetine işaret edilmektedir:

Helāk olur ḳamu eşyā-yı mevcūdāt illāhū

Ki dā'im Ḥayy u Bākỉdir münezzehdir helāketden (146. Beyit)

"Keşke toprak olsaydım." (Kur'an-1 Kerim 78: 40) ayetinden iktibas yapılmıştır:

Olar ḩāk olalar ol gün cehennem içre senden ün

Gele yāleyteni küntü türābā diyü hasretden (257. Beyit)

"Andolsun biz, cinlerden ve insanlardan birçoğunu cehennem için yaratmış olduk. Bunların kalpleri vardır ama onlarla kavrayamazlar; gözleri vardır ama onlarla göremezler; kulakları vardır ama onlarla işitemezler. Onlar hayvanlar gibidir, hatta daha da şaşkındırlar. Isste asıl gafiller onlardır." (Kur'an-1 Kerim 7: 179) ile "Allah'ın lütfettiği nimete nankörlükle karşılık verip sonunda toplumların helake uğrayacakları yere, cehenneme sürükleyenleri görmedin mi?" (Kur'an-1 Kerim 14: 28) ayetlerinden iktibas yapılmıştır:

Ya ke'l-encām olup bel hum edall denilendensiñ

Teniñ dārü'l-bevār içre yine dār-1 gazāretden (245. Beyit) 


\section{Hadisler}

"Sen olmasaydın, sen olmasaydın felekleri yaratmazdım" (İmâm-1 Rabbânî, 2019, s. 523) hadis-i kutsisine işaret edilmektedir:

Ol olmasaydı olmazdı bu carş u ferş ü kürs eflāk

Kime virdi ki virdi ol celīl aña celāletden (43. Beyit)

"Dünyada sanki bir garip veya bir yolcu gibi ol" (Buhârî, Es-Sahih, Rikak 3) hadisinden iktibas yapılmaktadır:

Çü geldiñ cāleme yolcı gibi ol yā garīi imdi

Temāşā eyle cibret al imāret ḳılma nehmetden (131. Beyit)

"Allah ümmetimi dalalette birleştirmez (dalalette birleşmelerine izin vermez). Allah'ın (yardım) eli cemaatin üzerindedir. Cemaatten ayrılan ateşe ayrılmış olur" (Tirmizî, Sünen, Fiten 7) hadisine işaret edilmektedir:

Buyurmuşdır Resūlu'llāh ider şol kim cemācat terk

Olur ol dört kitāb içre gümānsız ehl-i āfetden (13. Beyit)

"Üç kişi bir köyde veya kırda bulunur ve namazlarını cemaatle kılmazlarsa, şeytan onlara hâkim olur. Öyleyse cemaatten ayrılma. Çünkü kurt ancak sürüden ayrllan koyunu yer." (Ebū Dâvūd, Sünen, Salât 47) hadisine işaret edilmektedir:

Daḩi ki olmaya ḥāżır cemācat birle beş vaḳte

Dimiş selb ola ỉmānı dem-i āḩirde gāretden (14. Beyit)

"Kim başına gelene rizâ gösterirse, Allâh ondan hoşnud olur. Kim de rizâ göstermezse, Allâh'ın gazabına uğrar." (Tirmizî, Sünen, Zühd 48) hadisine işaret edilmektedir:

Şeḳāvet ehli olan hōod cehennemlik-dürür şekk yoḳ

N'içün ḳorḳmayasın her dem bes ol dar-1 beşāaatden (29. Beyit)

"Zevkleri bıçak gibi keseni -ölümü- çok hatırlayın." (Tirmizî, Sünen, Zühd 2) hadisine işaret edilmektedir:

Eger fikr itseñ ölmekden ölüm ḥāline gelmekden

Olup bīzār gülmekden ölüm geçdigi her mertden (64. Beyit)

"Kim arkadaşının ayıbını örterse, Allah da kıyâmet günü onun ayıbını örter. Kim ki Müslüman kardeşinin ayıbını açığa vurursa, Allah da onun ayıbını açı̆̆a vurur. Hattâ evinin içinde bile olsa onu ayıbıyla rezil eder." (İbn-i Mâce, Es-Sünen, Hudud 5) hadisine işaret edilmektedir:

Görüp bir kişiniñ caybın ḳılursın lag̉v u istihzā

Seniñ caybın hōd añmazsiñ belā bu kim belādetden (92. Beyit) 


\section{Atasözleri}

Eken biçer, konan göçer:

Cihān bir kār-bānhāne-durur ḳonan göçer elbet

Gedā vü şāh ḳul neyse cașāletden fesāletden (140. Beyit)

Ne ekersen onu biçersin:

Ve-likkin her ne ekdiñse bütün ol-dur yine az çok

Eküp erzen eruz ummaḳ cabeșdir ol ḥırāsetden (85. Beyit)

\section{Deyimler}

Aklını başına almak (toplamak, devşirmek):

Gel imdi caklıñ devşir rücūc it eyle istiğfār

Eger ḳurtulmaḳ isterseñ ḳıyāmetde melāletden (35. Beyit)

Aman vermemek:

İrişür mevt aman virmez emāneti gümān virmez

Alur cānı aman virmez dahi bir vaḳt-1 sā̄atden (119. Beyit)

Ana rahmine düşmek:

Atañ șulbına ag̉madın anañ raḥmine düşmedin

Dahii bu yurda ḳonmadın ne yerdeydiñ bidāyetden (96. Beyit)

Ayak basmak:

Bu yurța çün kadem bașdıñ ebed ḳalmag̉adır ḳașdıñ

Ḳo bu fikr-i muhāali kim bu hāàle yoḳ icāzetden (41. Beyit)

Başa çıkmak:

Bunuñla başa kim çı̣ $d ı$ ki ey miskin çıḳasın sen

Ya vușlat-ile kim güldi kim ag̉lamadı firḳatden (106. Beyit)

Dem vurmak:

Nedir adıñ ne yerdensin ne milletden urursın dem

Agga misın veyāhuut ḳul ḩaber vir bir emāretden (70. Beyit)

Dili dolaşmak:

Nice idim ben anlarıñ cemālinden kemālinden

Ki diller țolaşur şaşar caḳıllar ol belāgatden (233. Beyit)

Gönül almak:

Ne al-ile alur körsüñ bu zālim ādemiñ göñlin

Mutī olur murādınca biraz vaḳt istimāletden (119. Beyit) 
Gönül vermek:

Ne șandıñ cālemiñ bilmen bu naḳş-1 bì-vefāsını

Gönül virdiñ görüp biñ biñ șafā ile șabāvetden (102. Beyit)

Gözüne uyku girmemek:

Eger bir vaḳt namāz içün bileydiñ nic'olacaġiñ

Ne gözüñe geleydi uyhu une göñlüñ mecācatden (16. Beyit)

Gözünü açmak:

Hey aç gözüñi bijdār ol uyar caḳlıñ ḩaber-dār ol

Ne yoldır gitdügiñ fikr it ne yerdir vehl u vahşsetden (170. Beyit)

Kalbi kararmak:

Ḳoyuban diliñi hū di dil ü cān-ile yā hū di

Kararmış ḳalbimi yu di kerem ḳıl āb-1 şefḳatden (270. Beyit)

Kul olmak:

Kul oldıñ şöyle ki emrin ḳomazsın bir nefes anıñ

Yelersin yolına dün gün șabā gibi șabābetden (104. Beyit)

Yerli yerinde olmak:

Șalat u șavm ayına vār süvār ol yerlü yerinde

İşiñ bu yolda olsun $\mathrm{sa}^{c} \mathrm{y}$-ile cüst ü cesāretden (186. Beyit)

Yüz çevirmek:

Cihān kim bir kişiden yüz çevire terk ide luṭ̂n

Hemān ḳahr itmek ardınca olur āni neḳāżetden (127. Beyit)

Yüzüne gülmek:

Yüzüñe güldügin gerçek șanup sevdiñ bu murdārı

Seniñle bir iki gün bu ḥarif olur ḥafāvetden (103. Beyit)

Yüz karası olmak:

Şu deñlü kim günāh itdiñ ḳazandıñ yüz ḳarasını

Eger ḳılmaz-iseñ tövbe 1rāḳ oldıñ şefācatden (22. Beyit) 


\section{METIN}

\section{KASĪDE-İ ŞİNĀSİ}

\section{Mefācīiün / Mefācīiün / Mefācīiün / Mefācīiün}

1. Nice uyursin ey gāfil uyan bu ḩ āb-1 gafletden Ne noḳșān eylemişsin țur ḥesāb it gör emānetden

2. Adıñ mü'min ola miskīn emīni olasın Haḳḳıñ

Revā mıdır aña lāyık işiñ yoḳ istikāmetden

3. Emānetden murād olan kelām u nefs u māl oldı

Daḩi söz çoḳ eșaḥh ammā șalāt oldı ṣıyānetden

4. Saña çün bu emāneti ricāyet it didi Allāh (1-b)

N'içün pes żāyic eylersin șaḳınmazsın ḩıyānetden

5. Zihī ḳorḳusuz ādemsin ki ḳoyup pādişāh emrin

Uyarsın nefse olmazsın berį bir dem tebācatden

6. Eger bir zerrece havfiñ olaydı Hayy u Bāḳįden

Dürişirdiñ gice gündüz ușanmazdıñ cibādetden

7. Müselmānım deyü dac vi ḳılursın belki cālemde

Bu da ${ }^{c} v i ̣$ olmag̉a sābit getür ne'ñ var calāmetden

8. İşiñ tezvīr ü telbīs ü nifāḳ u iftirā hịile

Nice dirsin Müselmānım utanmadan bu hāletden

9. Eger dirseñ şehādetdir hemān aṣl olan İslāma

Kavil kim uymaya ficle düşer kişi şehādetden

10 Tamām olur mı șanursın hemān tevhịid ile İslām

Bile olmayıcaḳ șavm u șalat-ile țahāretden

11. Saña emr oldı Hुālıḳdan ki beş vaḳtde namāz eyle

Beyān oldı daḩi vaḳti ezāan-ile iḳāmetden

12. Sen anı günde beş kerre işidir hāżı̀r olmazsın

İki cālemde mel'ūnsın çün ayrusın cemācatden (2-a)

13. Buyurmuşdır Resūlu'llāh ider şol kim cemācat terk Olur ol dört kitāb içre gümānsız ehl-i āfetden

14. Daḩi ki olmaya ḥāżır cemācat birle beş vaḳte Dimiş selb ola ỉmānı dem-i āhirde gāretden

15. Cemācat terk iden böyle olıcaḳ var ḳıyāṣ eyle Namāzı terk iden neyle hyalāṣ ola mehābetden

16. Eger bir vaḳt namāz içün bileydiñ nic'olacaġıñ ${ }^{1}$

Ne gözüñe geleydi uyḩu ne göñlüñ ${ }^{2}$ mecācatden

Kelime vezin gereği birleşik yazılmıştır. 
17. Olaydıñ giceler ḳā'im dahi yıllarca hem șā'im Geçeydiñ zikr-ile dā'im olup ehl-i riyāżetden

18. Cihāna gelmeden macni cibādet ḳılmadır yacni Koyup laġvı kesüp țacnı olup ehl-i șalāḥatden

19. Uyup nefs-ile şeyțāna idersin bunca ciṣyānı Meger işitmemişsin sözi ạ̣vāl-i ḳıyāmetden

20. Ya işitdiñ inanmazsın ḳıyāmet ola șanmazsın Pes andandır bu mücrimlik ya gāyet cāhiliyyetden

21. Bilür misin n'olısarsın ölüp țopraḳ olısarsın (2-b) Ne kim itdiñ bulısarsın nefāsetden nifāsetden

22. Şu deñlü kim günāh itdiñ ḳazandıñ yüz ḳarasını Eger ḳılmaz-iseñ tövbe irāḳ oldıñ şefācatden

23. Günāh itdiñse ger bunda nedāmet ḳılasın anda Ve-likin olmaya aṣṣı o vaḳt olan nedāmetden

24. Eger șoru ḥesāb olmaz dir-iseñ kāfir olursın Ger olur dir-iseñ n'içün șaḳınmazsın cināyetden

25. 'Aceb gāfilsin uyupsin bugün şol nefs-i bī-dīne Murādını virüp eksik ḳomazsın hiç ricāyetden

26. Zihī nādān imişsin kim o yoldāş olduğıñ kimse

Diler ḳurtarmaya hergiz seni küfr ü ḍalāletden

27. Bugün şol deñlü ḩarc itdiñ fesād u fisḳa cömriñ kim Hualās olmag̉a söz vardır saña yarın ḥaḳāretden

28. Tolı baḩl u hased cucb u cinād u buggżla ḳalbiñ Bu hạāl ile olan kimse olur ehl-i şeḳāvetden

29. Şeḳāvet ehli olan hōod cehennemlik-dürür şekk yoḳ N'içün ḳorḳmayasın her dem bes ol dār-ı beşāaatden (3-a)

30. Eger ben mü'minim dirsiñ neden dirsin delīliñ ne Ne zāhir eylediñ ḳani cibādetden ițācatden

31. Bırag̉up gayret u cārıñ müsāvī söylemek kārıñ Kaçan mü'min olursın çünki var sende bu cādetden

32. Bilinmişdir bugün bunda ḳamu mü'min münāfıḳ hep Kimi ef āl aḳvāl u kimi dīn ü diyānetden

33. Nişānın her biriniñ pes dimişdir Ḥażret-i Server

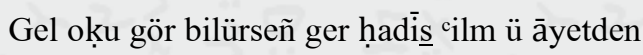

34. Söziñ kizbb ü öziñ fitne işiñ kibr ü riyādır Münāfıḳsın gerek ḳaḳı gerek küs bu maḳālatdan

2 Vezin gereği yönelme hâl eki yazılmamıştır. 
35. Gel imdi caḳlıñı devşir rücūc it eyle istiggfār Eger ḳurtulmaḳ isterseñ ḳıyāmetde melāletden

36. Bu huūlardan yüri fikr it ve ger var-ise çok zikr it Eger yog-ise var şükr it șaḳın daḩi sirāyetden

37. Eger var-ise terk it Müselmānlığı berk it

Ger itmezseñ şaḳižzsın nașīibiñ yoḳ sacādetden

38. Ne ḩavfiñ var ilāhıñdan ne āhıñ var günāhıñdan (3-b)

Ne olmañ var fikriñden ne gitmek bu vilāyetden

39. Benimsidüñ mi bilmem bu ḩarāb olası dünyāyı

Bir iki gün yiyüp içüp yatup țurmaḳla rāḥatdan

40. Yıḳup dīnüñ yaparsın habu vīrān olıcaḳ yurțı

Bu hūalar Hāâlı̣a külli calāmetdir cadāvetden

41. Bu yurța çün ḳadem bașdıñ ebed ḳalmagaadır ḳașdıñ

Ko bu fikr-i muhāāi kim bu hạāe yoḳ icāzetden

42. Eger ḳalmaḳ olaydı ol nebīer şāhı ḳalaydı

Henüz maḳṣūdı olaydı bu maḩlūḳātı hilḳatden

43. Ol olmasaydı olmazdı bu carş u ferş ü kürs eflāk

Kime virdi ki virdi ol celīl aña celāletden

44. Mufașșal eyledi anı cemic-i yaradılmışdan Huuṣūṣā ol ḥabībiydi resūliydi risāletden

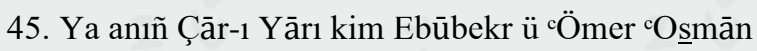
cAli-yi murtażā kim her biri serverdi sādātdan

46. Olar ḳalmadı dünyāda saña baña çü-kim ${ }^{3}$ dirler

Gel imdi dön nedāmet ḳ̂l bu yerde istidāmetden (4-a)

47. Ne șanursın bugün yarın gidersin sen dahi bundan Seniñ gibi degil midir gelüp giden bu sāḥātden

48. Egerçi istirāḥatdir murādın virdigiñ nefse

cUkūuet ola 'uḳbāda velī ol istirāḥatden

49. Ne deñlü kim bugün bunda nezāhet nüzhet eylersin

Te'essüf ḳılasın anda bu nüzhetden nezāhetden

50. Yaraşmaz dār-1 dünyāda meserret mü'mine zīrā

Kişi dünyāda şād olmaḳ olur gāyet ḥamāḳatden

51. Müselmān olana lāyıḳ budur kim ag̉laya çoḳ çoḳ

Döküp gözyaşların ḳorḳa ḳıyāmetde ḩarābetden

52. Aña cișyānını dā'im nedāmet ḳıla ḳalbinden

Dahii olmaya bir sācat berī hüzn ü melāletden

Nüshada "çünkim" şeklinde geçer. 
53. N'içün mesrūr olursın pes degilsin mest ü divāne Meger var-ise echelsin bu macnā-yı cibāretden

54. Ne mesrūr olıcak yerdir bu yer ha olısarsın sen Bu yerde her ki ḳuldır selīm olur selāmetden

55. Ḳo şād olma ki ġam-gīn ol tevāżuc ehli miskīn ol (4-b) Yeter hōō-re'y-i huūr-bīn ${ }^{4}$ ol gel uṣlan geç sefāhetden

56. Teferrüc ḳılmaḳ isterseñ eger vech-i lețāfetden Düriş āyīne-i ḳalbiñ mücellā ḳ̂l kesāfetden

57. Halāṣ ol hāaliṣ ol dā'im añ iḩlāṣ-ile Allāhı Sivādan țāhir it ḳalbiñ tecennüb ḳıl cināyetden

58. Cihān-cennet olanlardan olursañ ḩōd işiñ belli Yeriñ nārı yemek zaḳḳūm ola içmek cerāḥatden

59. Aña vay kim ola anıñ maḳāmı maḥfel-i fi'n-nār Yanup bir demde biñ kerre bite yine harāretden 60. Anıñ gibi ḥarāret kim şunı̃ gibi merāret kim cAzzābı günde yüz biñ kez eser ola ihānetden

61. Ne ölmek var ne dirilmek ne şefḳat merḥamet her kim Ne hāli olma var bir dem cezā vü zecr-i zaḥmetden

62 Añup bu ḥāli pes n'içün perişāan olmayasın sen Seniñ var m1-durur yacnī berātıñ siyāsetden

63. Ṣafā-y1 żevḳ-i nefsānī unutdurmış saña mevti Anıñ-çün āḩiret ḥālin geçürmezsin ferāsetden (5-a)

64. Eger fikr itseñ ölmekden ölüm hāaline gelmekden Olup bīzār gülmekden ölüm geçdigi her mertden

65. Ölüm dimek egerçi-kim dile āsān bir sözdür Veli ol dem nice demdir içen bilür o şerbetden

66. Gerek gamdan bu aḥvāli añup olmayadıñ ḩāli Meger gāyet bürünmüşdir göziñ ḳalbiñ ḳasāvetden 67. Hey uyanıgör uyhudan kesil cüdāyla ol huūdan Emīn olma bu ḳorhudan șaḳın Haḳḳdan ferāgaatden 68. 'Aceb hiç fikr ider misin gelişiñ bunda ḳandendir Ya girü ḳande ḳonarsın küçicük bu cimāretden 69. Ya sen kimsin ne iş içün seni gönderdiler bunda Nice ḩidmet edā itdiñ cadāvetden șadāḳatden 70. Nedir adıñ ne yerdensin ne milletden urursın dem Ag̉a mısın veyāḩut ḳul ḩaber vir bir emāretden

4 Nüshada "huūrde-bìn" kelimesi "hūr-bìn" şeklinde yazılıdır. 
71. Ḳul-iseñ ḳulluḳ itmekden n’içün írāż idersin Ṣıyup Mevlāñıñ emrini olursın dūr hidmetden

72. Ger ag̉asın bu iḳlīmi saña tīmār kim virdi (5-b) Ne ḳıldıñ şāh içün ḩidmet ne gösterdiñ besāletden

73. Șıyup şeyțān çerīini zebūn itdiñse ger bunda Pes ag̉alıḳ nedir beglik bulasın ol şecācatden

74. Vü ger tābīi olup nefse muțīi oldıñsa şeyțāna Ziyān içindesin yoḳdur saña sehm istifādetden

75. Müselmān iseñ emrīñi șaḳın zinhār ha zinhār Tekebbürlük idüp emrin șımasın istihānetden

76. Eger bilseñ ki sen kimsin ne gevher macdenindensin Ne virmişdir saña yāhūu Kerīma'llāh kerāmetden

77. Ṭarīḳ-ı rāstdan țaşra ḳomazdıñ bir ḳadem pāyıñ Daḩi 'ömrüñde ḳılmazdıñ gażāżetden buġāżetden

78. İderdiñ it didüginden giderdiñ git didüginden Ḳılurdıñ Rabbiñi rāżī olurdıñ ehl-i cennetden

79. Dirīgāa bilmediñ ḳadriñ cehennem eylediñ șadrıñ Uyup nefse zelīl oldıñ nüzūl itdiñ siyādetden

80. Uş az ḳaldı çıḳarırlar seni bu milk-i fānīden Bilürsin kimsin ol vaḳtde işāretden beşāretden (6-a)

81. Ne didim hịç işitdiñ mi Haḳ-içün bir iş itdiñ mi $\mathrm{Ki}$ ol bir iş-ile bārī umasın sen de raḩmetden

82. Ümīd üzmek egerçi kim ḩațādır raḥmet-i Haḳḳdan cAmelsiz ummaḳ ammā kim olur lā-yı lebābetden

83. Zirācat itmedin zīrā getür kim götürür hāṣıl Dem olur zirācatden de ḥāṣıl olmaz āfetden

84. Hele evlāsı ol-dur ki eger andan uma hāṣıl Pes eyle umsa her nice yaraşur istirāretden

85. Ve-likkin her ne ekdiñse bütün ol-dur yine az çok Eküp erzen eruz ummaḳ cabeșdir ol hịāāsetden

86. Sen ekdügüñ șoġan ola ol aḳ buġday ḳaçan ola Ger eklerseñ hemān ola bu elfāẓ-1 kitābetden

87. Ne gāfil kimse imişsin $\mathrm{ki}^{5}$ hiç söz saña kār itmez Ne cāhil kimse imişsin ki duymazsın işāretden

88. Ġarūretden gurūruñ şol ḳadar mag̉rūr-1 dünyāsın $\mathrm{Ki}{ }^{c} u k ̣$ ā sözlerin yanḳu șanursın ol garāretden

5 İki mısranın uyumuna bakılarak “ki” bağlacının nüshada sehven yazılmadığı düşünülmektedir. 
89. Seni sen bilmeyüp böyle idersin cahd ${ }^{6}$ emānet żayc (6-b)

Zalūm oldıñ cehūl oldıñ garīb oldıñ vilāyetden

90. Ne țutdıñ emr-i Hallāḳı ne hōōd uydıñ resūline Zihī bedbaḩt imişsin kim berīin farż u sünnetden

91. Mesācidden ḳaçarsın sen varırsın lehv ile lucbe Șaḳalıñdan utanmazsıñ șaḳınmazsın feżāḥatden

92. Görüp bir kişiniñ caybın ḳılursın lag̉v u istihzā Seniñ 'aybın hōd añmazsı̃̃ belā bu kim belādetden

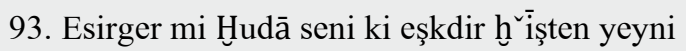
Yitirdiñ mezheb ü dīni dirīgā istiḥāretden

94. Nitekim bu enāniyyet seniñ ḳalbiñde ḳā’imdir Hemişse dūr ider seni 'Azāzil gibi Ḥażretden

95. Saña kim dirler ey cāciz ${ }^{7}$ idersin böyle istikbār Neyin dirsin veyā gögsiñ gerüp gülmeñ işāretden

96. Atañ șulbına aġmadın anañ raḥmine düşmedin Dahi bu yurda ḳonmadın ne yerdeydiñ bidāyetden

97. Unutduñ mı neden hạașıl olup geldiñ eyā miskīn Ne ḳabdan ḳaba ḳoyuldıñ veyā ḳable'l-vilādetden (7-a)

98. Ne ḥālden ḥāle ḳoydılar getürdiler seni fikr it Gelince cālem-i cisme bulınca bu beşāşetden

99. İki kez bevl yolından gelen mā'ī vü menīdensin Seni īcād idüp Mācid saña virdi şehādetden

100. Eger ol geldügiñ yollar geleydi göñlüñe gāh gāh Olaydıñ zemm-i dil dā'im berí olup ḍalāletden

101. Gelelden bundasın ammā unutdıñ aṣl u faṣılıñ Görüp dünyāyı ḳapladıñ müzeyyen hüsn-i șūretden

102. Ne șandıñ cālemiñ bilmen bu naḳş-1 bī-vefāsını Göñül virdiñ görüp biñ biñ șafā ile șabāvetden

103. Yüzüñe güldügin gerçek șanup sevdiñ bu murdārı Seniñle bir iki gün bu ḥarif olur ḥafāvetden

104. Kul oldıñ şöyle ki emrin ḳomazsın bir nefes anıñ Yelersin yolına dün gün șabā gibi șabābetden

105. Ne sevdādır bu hey dīvāne sen ḳanden cihān ḳanden Ki '1şș̣-bāzlı̣̣ ḳılasın cihān ile cehāletden

106. Bunuñla başa kim çıḳdı ki ey miskīn çıł̣asın sen (7-b) Ya vuṣlat-ile kim güldi kim ag̉lamadı firḳatden 
107. Buña böyle özenmekden seniñ idünmek istersin Olur sevdā degil geç ol ḩayālle istiḥāletden

108. Seniñ gibi degil biñ ${ }^{8}$ dalavereler bu dünyāyı Bizim olsun deyü dün gün dürişdiler nehāketden

109. Ezel gösterdi mühründen șınup șaḳındı ḳahrından Șunup șoñ avcı zehrinden helāk itdi felāketden

110. Buña her kim mürīd oldı bu anı nā-murād itdi Kimesne irmedi maḳṣūda bu kāni h hasāmetden

111. Buña maḥrūm olan bī-şekk olur maḥrūm-1 fi'd-dārın Vefādan bunda ve anda șafādan yacnī țalcatden

112. Dön ey dünyāya dil virüp șaḳınmayan bežāžetden Ki zevkḳi zehr olur bīzār olursın ol lezāāzetden

113. Hey ol bir bī-vaḳāretdir ki hiç yoḳdur șebāt anda Göñül virmek aña lāyıḳ degil merde mürüvvetten

114. Katı mekkāredir aldar çı ḳarır ādemi yoldan Görinür şīve-nāz-ile ki zībā ḳadd-1 ḳāmetden (8-a)

115. Diler mag̉rūr idüp ḩalḳı ḳıla maḥrūm iken mạ̣rūm Temāşā ḳıldurup kendüyi dürlü dürlü zīnetden

116. Murādı bu ki sevdürüp özini saña ol cāzū Ala sermāyeniñ varın bu nāz-ile nezāketden

117. Hezārān șad hezārān ol seniñ gibileriñ naḳdiñ Alup-durur elinden bu hayāl ile ḩalābetden

118. Zihī cayyāre kim çoḳdur hayālātı nuḳūşātı Zihī mekkāre kim yoḳdur naẓiri mekr ü hịiletden

119. Ne al-ile alur körsüñ bu zāalim ādemiñ göñlin Mutīc olur murādınca biraz vaḳt istimāletden

120. Żamīr-i dünyevisinden rıżāsın eyle gözler kim Muīcn olur ne dilerse aña her dürlü hāācetden

121. Döner andan bir iş eyler ki bilmez n'olduğın ādem Ṣıyup nā-gāh cahdini șunar bir zehr cāhitden

122. Mey-i merg-ile mest eyler hevā humḩānesindeyken Ol esriklikden ol bī-çāre bulmadın ifāḳatden

123. İrişür mevt aman virmez emāneti gümān virmez (8-b) Alur cānı aman virmez daḩi bir vaḳt-ı sācatden

124. Bilür andan nic'olduġın ${ }^{9}$ hemān bu miskīn ol günden Göçer nā-çār olup bundan geçer milk ü mekānetden

8 Nüshada "biñ" kelimesi iki defa yazılmış olup bir tanesi vezin gereği yazılmamıştır.

9 Kelime vezin gereği birleşik okunmuştur. 
125. Pes ol țūl-i emel ḳani ki eglerdi müdām anı Gör imdi n'itdi ol fāni aña āḩir hudācatden

126. Ezel yil virdi yeldirdi yüzine güldi güldürdi Dönüp al itdi öldürdi gażāżatden feẓāżetden

127. Cihān kim bir kişiden yüz çevire terk ide luṭfın Hemān ḳahr itmek ardınca olur ānī neḳāżetden

128. İşitdiñ didim uş kārın ki n'eylermiş ḩarīdārın Bunıñla uṣlu bāzārın bozar biraz ifādetden

129. Şikāyet eylece itdim hịikāyet hāal-i cālemden Ki ḥiṣṣe ala tā bu ḥikāyetden şikāyetden

130. Dir imdi caḳlıñ ey rehber țur imdi diñle peyġamber Ne buyurmış gör ol Server kelām-1 pür-ḥalāvetden

131. Çü geldiñ cāleme yolcı gibi ol ya garīb imdi Temāşā eyle cibret al imāret ḳılma nehmetden (9-a)

132. Baḳup ḳabr ehline ḳorḳar hemiş̧e nefsiñ anıñla Kim-idi her biri fikr it șabāḥatden ḳabāḥatden

133. Ki sen dahii olar gibi ölürsin şekk degil zīrā Olar daḩi seniñ gibi mekân-dār idi miknetden

134. Ḳoyup fermān-1 raḥmānı düzerlerdi düzenleri Daḩi evțān-ı şeyțānı bezerlerdi bezāaretden

135. Biribiriniñ üstüne yaparlar yüce çardaḳlar İderlerdi için țaşın mușannac dürlü șancatden

136. Ölem dimezdi hiçbiri benimsemiş-idi bunı Ecel irdikde tedbīiri ḳamunıñ oldı haybetden

137. Şular kim dā'imā tābic olup nefs ārzūsına Ṣalāt erkānını żāyic iderlerdi rekāketden

138. Bu vech-ile ki gavġā-yı cihāna uydılar āḩir İletdi anları gayyāya ol gavgāa ġyābetden

139. Pes imdi bu beş on günlük cömürden ötrü dünyāda Nedir bu re'y-1 rifḳlar n'olur bu hūy nuhuvvetden

140. Cihān bir kār-bānḩāne-durur ḳonan göçer elbet (9-b) Gedā vü şāh ḳul neyse cașāletden fesāletden

141. Ve-likkin her biri nevbetlüdir kim ir göçer kim geç Gelüp ḳondıñ çü sen dahi göçersin vaḳt-ı nevbetden

142. Seniñ ardınca bir iki beş on yüz biñ ḳaç olursa Gelür gider bu cālem tā tamām olınca müddetten ${ }^{10}$

10 Nüshada bu beytin mısraları yer değiştirmiştir. 
143. Seniñ ammā żamīr-kejde bu añlanur ki gitmezsin Kalursın bunda ölmezsin selāmet birle selvetden

144. Seniñ hey ol ḩayālindir cabes fikr-i muḥāliñdir Gelen geçmek ḳonan göçmek-durur cādet bu beritden

145. Bu șı̣̣ḥat birle șoḥbet böyle ḳalmaz çerh-durur bu çerh N'idem gaāfilsin ey bāḡi be-ḡāyet baġy-ı baġyetden

146. Helāk olur ḳamu eşyā-yı mevcūdāt illāhu Ki dā'im Ḥayy u Bākīidir münezzehdir helāketden

147. Anıñdır raḥmet ü ḳudret çerā çün dimez kimse Dirildir öldürir tā ki ider ḥükm-i hüukūmetden

148. Seni ol bunca aṣlāb-ile erḥāmdan getüren şāh Girü giderse ḳādirdir aḩi fevt-ile ḳudretden (10-a)

149. ' Adem mülki țarị̣̂ından vücūd iḳlīmine geldiñ Fenā şehrinde birḳaç gün ḳarār itdik remādetden

150. Bir iḳlīme dahi varsı̃ gerek ammā gidüp bundan Kalam șanurdıñ olasın bu yerde belki ruhșatdan

151. Ve ki gelmekde ol yoldan gelen bì-ḩavf gelmişdir $\mathrm{Bu}$ yolda böyle gitmekde görünmek var hüccetden

152. O vaḳtde hüücceteñ maș̣ūm-1dıñ külli günāhdan pāk Daḩi ḩaddām-idi bunca melekler saña ciṣmetden

153. Yüküñ tevhịid idi yacni saḳil ammā cale'l-mīzān Te'essüf zāāt içün zātıñda hem yog̀-idi vaḥdetden

154. Daḩi hem nuṣretu'llāh idi saña hem-rāh Ḥādī Gülerdiñ gușșadan ḩālì vü dā'im țolı behcetden 155. ... ${ }^{11}$

Kişi ki ${ }^{12}$ ḳorḳusuz āsān gide bu rāh-1 garetden

156. Ve-līkin bilmediñ sen bu sacādet șadrınıñ ḳadrin Şekāàvetle cüdā ḳaldıñ öziñ cāy-ı ḥaḳiḳ̣atden

157. Kaçan-kim uġradı rāhı̃ bu ḩār-gāh-1 güzergāha Hemān yoldan șapup gitdiñ düşerdiñ hicr ü vuṣlatdan (10-b)

158. Ġıā-yı rūḥ ya`ni zikr ü tesbiḥ idi terk itdiñ Ġıdā-yı nefse aldandıñ dirīgā kec rü’yetden

159. Unutdıñ țālib-i rızḳ-ı fenā olmaḳla Rezzāḳı Beḳā yolunda azdiñ kec țamacyla kem țabīcatden

160. Kelām u reh-nümāya uymadıñ yañlış yola gitdiñ Bu kez gümrāh olup hem-rāhı yitirdiñ lecācetden

11 Bu misra nüshada mevcut değildir.

12 "Ki" kelimesinden sonra gelen "ol" kelimesi vezin gereği yazılmamıştır. 
161. Șanırsın sen dahi ammā bu gitdügiñ yol ol yoldur Veli fehm eylemezsin kim çıkupsın ol muhabbetden

162. Meleklerden cüdā düşdüñ şeyāțīn oldı yoldāşın O lā-dīnle ne yola kim yüridüñ oldı zulmetden

163. Günāhlar baḥrına țaldıñ ḩațālar cemc-ile țoldıñ Ve-likkin bilmediñ n'oldıñ neye irdiñ vebāletden

134. Riyāya virdiñ iḩlāṣı degişdiñ cāmmla ḩāṣı Ne yavlaḳ azdıñ ey cāși çıł çup minhāc-1 şercatden

165. Şu deñlü bār-1 ciṣyānı ki yüklenmişsin ey cāṣi Nice menzil alursın pes bu eșḳāl u siḳāletden

166. Uzaḳ yolıñ yüküñ aġır uş az ḳalmışdır ey tācir (11-a) Göresin n'olduġıñ āḩir bu rıḥletden bu siḳletden

167. Hูafïfe'l-ḥiml olmazsıñ ḳalursıñ sen dü menzilde Daḩi bir dem berī olmazsın āh u vāh-1 vehletden

168. Sebük-bār olmayan zīrā bu yolda alamaz menzil İşi șa $a^{c}$ u şedīd olur emīn olmaz șucūbetden

169. Yük ag̉ırlı̀g yol țarlı̀ğ tenhālıḳ yaraḳsızluk Harāmi ḩavfı ḩōd dahi eşeddir cümle varțatdan

170. Hey aç gözüñi bīdār ol uyar caḳliñ haber-dār ol Ne yoldır gitdügiñ fikr it ne yerdir vehl u vahşsetden

171. Tefehhüm it bil özriñ hōod dönegör girü cehd eyle Hele n'itdüñse itdiñ gāfil olma cavdetden

172. Ola kim ol șırāṭ-1 müstaḳime geçesin tizcek Dalālet yollarında ḳurtulasız tār-māretden

173. Meger ol geldügiñ gibi girü bī-gam gidersin sen Ve illā ḩavf gālibdir saña bu rāh-1 rı̣̣letden

174. Bu yol ol yol gibi āsān degil düş-vārdır zïrā Cemī'-i ins ü cinn cāciz bu yolda havf-1 vahş̧etden (11-b)

175. Nice der-bendler vardır ki ḳorḳudan șarır ödler Pes uğrasiñ gerek elbetde elbetde żarūretden

176. İnanmazsın yaḳındır uş belāsın gördügiñ vaḳtde cAmel ḳalmayıcaḳ bilmek ne așșı ola firșatdan

177. Peşīmān olasın ol dem temennīidesin cavdet Revā olmaya ammā ol temennā-yı icādetden

178. İnanırsıñ ki taḥḳiḳan gidersin pes ne țurırsın Aña göre yarag் ile dürüş bu vaḳt-1 vüscatden

179. Bu yol gāyet ḩațarludır șaḳın yoldāşsız gitme Ki tā ḳurtulasın ṣag̉ u selāmet her meḩāfetden 
180. Saña yoldāş dedigüm țut cavāmm olmag̉ıl zinhār Ora ir himmet al andan hạạ̄'iḳ bul hidāyetden

181. Bu yolda niceler gāâl bulınup oldılar mag̉būn Yaraḳsız yaluñız gidüp olup evsāk-i cizzetden

182. Niceler gitmedin ḳıldı yaraġın vaḳt-ile ${ }^{13}$ ḥāżır Pes andan geçdi ḳurtuldı selāmet birle heybetden

183. Nedir dirsiñ yaraġını bu yolıñ zühd ü taḳvādır (12-a)

Daḩi ḳılmaḳ nedāmet tevbe istiğfār hümüvvetden

184. Şerī'at cevşenin giyin țarịkat cübbesin pāyın

Ki tā kār itmeye düşmān saña işbu hașāṣetden

185. İtāâat ḳılıcın daḳın șadāḳat gencini șaḳın cİbādet birle ol yaḳın berī olma bașāretden

186. Șalat u șavm ayına vār süvār ol yerlü yerinde İşiñ bu yolda olsun $s^{c} \mathrm{y}$-ile cüst ü cesāretden

187. Șalāḥiyyet silāḥınıñ ḳamusın idegör hāāżır Dahi denilmedin gel git saña emr ü irādetden

188. Bu yolda çoḳ-durur gāyet ḥarāmī ḥāżır ol zinhār Kemān u tīr-i tevḥidi șaḳın senden irāḩatden

189. Ne deñlü çoḳ yarag่-ile girersiñ yeñdürür yola Velī bir dem berī olma Hudādan isticānetden

190. Eger hem-rāh olmaya Haḳıñ luṭ̂-ı lațifinden Ne așș1 var yarag் 1 ñdan ne ḳılletden ne keșretden

191. Yarag்ına inandılar niceler gitdiler bundan Olara Ḥaḳk tecālādan nașīb olmadı nuṣretden (12-b)

192. Harāmī giderek āhir yaraǵ-ile yasaǵ-ile Alup naḳdin ḳodı maḥrūm oları bu seyāḥatden

193. Hele yol ehline lāyıḳ budır kim pür-yarag ola Yola andan gire Haḳka șiġınup șıdḳ-1 niyyetden

194. Tażarruclar ḳıl Allāh'a tevāżuclar it ol şāha Diler başad ki ḳılmaya seni maḥrūm icānetden

195. Eger cavn-1 ilāhīden seniñ-ile ola yoldāş Ḥarāmī kār ide hạaşā saña işbu mesāfetden

196. Metāc-1 șıdḳ u iḩlāṣı eger ḳurtarıbilürseñ Bulasın varasın anda bahā-yı bī-nihāyetden

197. Gel imdi sen seni tanı ne yerden geldiñ añ anı Ferāmūş itme fermānı firāset ḳıl ḥırāsetden

13 "Vaḳti ile" ifadesi vezin gereği birleştirilerek okunmuştur. 
198. Bu mülke çün ḥulūl itdiñ ne ficliñ fācili oldıñ Ne taclīm itdi gönderdi saña șānic șınācatden

199. Ne ögrendiñ ne işitdiñ ne dimek pişse idindiñ Nice rāh u revş idindiñ maḳālatdan iḳāletden

200. Bu ḩalḳ-ile ne ḩulḳ-ile dirildiñ bu vilāyetde (13-a) Ne pişse oldı ya maḥrem saña maḳt u muhabbetden

201. Nedir kārıñ ne kesb itdiñ ne virdiñ aldıñ aldandıñ Hesāb eyle çü sen bir kez ne var nef ${ }^{c} \mathrm{u}$ mażarratdan

202. Saña bunca ki sermāye efendiñ virdi gönderdi Bu sīretle olasın tā hemișe dūr c ${ }^{c}$ sretden

203. Daḩi hem kār-ḩāne bu fenā dārını emr itdi Saña var kesb eyle diyü virdi her āletden

204. Gelüp sen bunda żayc itdiñ hep ol alāt u esbābı Çıḳardıñ varıñı elden bacīd oldıñ ḥ̣ıāțatdan

205. Ne ser ḳodıñ ne sermāye ḳamusın fisḳa degişdiñ Ne dirsin șorıcak ḩ āceñ saña ḩayr u ḩasāretden

206. O sulțān-1 selāțīniñ ḥużūrına varup zīiā Ḥesāb-ender-ḥesāb olınacaḳsın bu ticāretden

207. Zihì sulțāndır kim vezīiri yoḳ naẓiri yoḳ Hemişe ferd $u$ ehaddır münezzehdir kemiyyetden

208. Anıñ zindānıdır țamu daḩi zindāncısı Mālik Zihī Mālik ki a vānı mucayyendür celādetden (13-b)

209. Pes ol vaḳtde ne cān-ile cevāba olasın ḳarār Su'āl oldıḳda žerre zerre tā iśm ü mesāābetden

210. Eger fażlına dūş oldıñsa ḳurtuldıñ ve illā vay Eger șorup ḳıla icrā her aḥkāmı cadāletden

211. Seni sen hükkm idüp nāre diyesin yaḳ beni yā Rab Ki biñ kez yeg-dürür yanmaḳ bu dem işbu ḩacāletden

212. Pes ol vaḳtde seni şöyle zebūn ide zebānīer Ölesin yüz kez ol hāāim dirilde yine ḳudretden

213. Anıñ gibi zebānīler ki gaażbānlar-durur gāyet Daḩi şol zişt-rūlardır ki baḳılmaz semāḥatden

214. İlāhī birlik-ileñ Haḳk șig̀ındıḳ saña sen șaḳla Olarıñ hem ḳulūbında ne raḥmet var ne re'fetden

215. Țutalar bend idüp muhkem ṣalalar ḳacr-1 nīrāne Kaçan çıḳasın ol cāh-1 gam-1 bī-ḥadd-1 gāyetden

216. Meger luṭf-1 ilāhīden cināyet irişüp ol-dem Diye cafv itdim āzād ol bu zindān-1 mezelletden 
217. Ve illā hoōd cehennemde muªzzzeb olasın dā'im (14-a)

Temenni idesin mevti belā vü derd ü mihnnetden

218. Hīç ol gün nic'olacaġıñ añar mısın bu dünyāda Ye şilkeñ mi var ol yevm-i melāmetde selāmetden

219. Bu ise ictiḳādıñ kim ölmek var artıḳ yoḳ

Dirilmek yine haşr olmaḳ șorulmaḳ hill u hürmetden

220. Küfürdür imdi bu muṭlaḳ gel istig̉fār ḳıl bi'l-ḥaḳ

Ki tā ayırmaya ol Ḥaḳ buları Haḳk dirāyetden

221. Bular hep vardır Ḥaḳḳdır ḳamusı olısar bī-şekk

Ḥisāb olmaḳ kitāb olmaḳ citāb olmaḳ ihānetden

222. Helāl içün hisāb ola ḥarām içün cazāāb ola

Ne kim itdiñ kitāb ola sevāb ḥayf vaḥdetden

223. Elüñe vireler ol ne deñlü var-ise mektūb

Oḳu cabdī deyü ire nidā eyvān u rifcatden

224. Eger oḳumaḳ yazmaḳ nedir hiç bilmezem dirseñ O vaḳt āsān ola gāyet oḳumaḳ cümle ḥırfetden

225. Oḳuyup göresin ḥāliñ ḳamu ḩayr u şer acmāliñ

Pes andan șoñra emr ola işüñe göre ücretden (14-b)

226. Eger Allāh emrini țutup şerc üzere oldıñ

Saña dārü’n-nevār içün ḳılalar hōōş żiyāfetden

227. Anıñ gibi żiyāfet kim ne göz ${ }^{14}$ gördü ne işitdi Ne geldi ḳalb-i insāna olan ol nevc-i nicmetden

228. Veyā ol hụ̄r-1 'aynlar kim mis̄āli lü'lü-i meknūn Mücellālar mücellālar mușaffālar neẓāfetden

229. Şu zībālar ki șadrında görinür her biriniñ nūr Birer nūr-1 mușayḳaldur ki yoḳdur zerre cilletden

230. Şu racnālar ki sāḳından iligi görinür rūşen Sekiñden țaşra atdın dahi yetmiş ḳat hilcatden

231. Biri barmağı țırnaġını gösterse dünyāya İdeydi maḥv anıñ nūrı güneş nūrın lețāfetden

232. Düşeydi baḥre bir ḳatre biriniñ aġzı yarından Hep ol deryā șuyı sükker olaydı ol ḥalāvetden

233. Nice idem ben anlarıñ cemālinden kemālinden Ki diller țolaşur şaşar caḳıllar ol belāgatden

234. Pes anlardan daḩi saña cațālar ideler anda (15-a)

Ola deñlü ḳalasın hōoş șafādan zeveḳ-i șoḥbetden

14 “Göz" kelimesi nüshada "gözler" şeklinde geçmektedir. 
235. Bulasız bī-ölüm dirlik dahi ayrılmaya birlik Zihì birlik ile dirlik muhalled ola ḩalletden

236. Saraylarda sürūr ile serīrler üzre sezāen İdesiz zevẹk ola deñlü ki şerh olmaz o lezzzetden

237. Daḩi şol züu'l-cenāḥ atlar mürettebler müzehhebler Ki yüz yıllıḳ yolı bir demde iderler seyr sürcatden

238. Hem anlara süvār olup dahi uçmaḳda uçmaḳla Temāşā idesiz çoḳ çoḳ cacā'ibler cacāletden

239. Olar daḩi seniñ olsa daḩi anıñ gibi bī-ḥadd ${ }^{c}$ Aṭ̂yyetler ki cadd olmaz degil mümkün kiyāsetden

240. Bu bir dil ile ben nice diyem evṣāf-1 cennetden Ki cācizdir ḳamu șāḥib-rivāyet ol reviyyetden

241. Eger her biri maḩlūḳuñ biñer dil ile şerh itse Cihānda cömri oldıḳça dükenmez ol hịkāyetden

242. Aña kim olmaya gāyet nihāyet kim bile anı Güneşden žerredir ancaḳ ki iderler ḥașāfetden (15-b)

243. Ne ölmek var ne șayrulık ne diş baş ag̉rısı hergiz Hemān her dem tenacumla selāmet var șı̣̣hatden

244. Eger acmāl-i șāliḥle dirildiñse maḳāmıñ ol Ebed olasın ol ābād içinde ehl-i cişretden

245. Ya ke'l-encām olup bel hum edall denilendensiñ Teniñ dārü'l-bevār içre yine dār-1 gazāretden

246. Ki yacnī dört ayaḳlular gibi oldıñsa cālemde Seni bir issi ahura ḳoyalar ḩōş ḥimāyetden

247. Anıñ gibidir issisi ol ahuruñ ki țamudan Erir bir demde ten biñ kez ölür ol sine ḳasvetden

248. Dahî ālāt u envā'-yı cazaāb ile içi memlū Her ālet-dār ki her dem ḳıla riḳḳat meşaḳḳatden

249. Ya ḥayyāt u caḳārib ki üşüp ger ideler lesḳa Biriniñ gitmeye șayrusı dahi acısı etden

250. Ḳo bu ag̉lālı enkāli ki dil şerḥ itmez ol ḥāli Dükenmez ḥaşrdeñ ḳāli disem nevc-i cuḳūbetden

251. Pes ol baḥr-1 belā içre bulasın cevr-i cāvidān (16-a) Ḳ1lup garsāan u caţ̧̦ān olup me’yūs igāạsetden

252. Semūm içre ḥamīm içüp şarābıñ ola şürbü'l-ḥīmm Ġażāb üstüne vardıḳça gażāb ola ziyādetden

253. Hep ol bunda ḳazandugiñ fesād işler-durur anda Gelüp her biri bir dürlü şikence ola şiddetden 
254. Zihī bī-cārlıḳ kim bu șığırlardan eşeklerden Sen azğun olasın her dem şeḳāvetle şenācatden

255. Olur hâ̄şā ki Mevlāsı sözin șıyup ola cāṣi Ne emr oldısa işlerler niye-kim yetse kudretden

256. Sen anlardan daḩi kimsin ḳatı oñmadıḳ ādemsin Zihì rüsvā-yı cālemin ki sensin ehl-i bidcatden

257. Olar hāak olalar ol gün cehennem içre senden ün Gele yā leyteni küntü türābā diyü ḥasretden

258. Yanası ol șıfatlar kim didiñ hep kendi şehriñde Riyā vü hịile ḍall ü naḳm var maḳt u nuḳimetden

259. N'içün sen ol șıfatlarla olasın muttaṣıf her dem Ne yüzle raḥmet umarsın pes ol dergāh-1 cizzetden (16-b)

260. Kaçan sen yaḳın olasın bu aḩlāḳ-ile Huallāḳa Ki bir dem olamazsın sen bu huūlarla ḩabāșetden

261. Vücūduñ mülkine sultān iken bu șaḥn-1 ṣı̣̣ḥatde N'içün aḥkām-1 şerc üzre degil emriñ emāretden

262. O şehriñ vay ḥāline kim olasın anda sen ḥākim Y1ḳılmasa cacebdir o hilāf-ile hilāfetden

263. Ḳılursın illere $v^{c} \mathbf{z}$ u nașị̣at çıḳuben kürse cAceb budur ki țutmazsın sen evvel ol nașị̣atden

264. Söziñden halḳ șanurlar seni bir șūfī vü șāfī Veli bilmezler anı-kim ne var ḳalbiñde şirretden

265. Seni bilmez miyim ben kim ne yüzi ḳara cāṣīsin Ne başlar gidecek țaşlar ḳoparırsın şerīatden

266. Eger ol sırrla itdügiñ günāhıñ birisin bu halḳ Bileydi seng-sār idüb yıḳaydı seni töhmetden

267. Eyā Allāhdan ḳorḳmaz revā mı olalar cāciz Fesād u fisḳdan her gün feriştahlar kitābetden

268. Gel imdi dön peşīmān ol it istiğfār giryān ol (17-a) Müselmān ol Müselmān geç ol küfrān-1 fikrinden

269. Benüm diyü benüm diyü düketdiñ cömriñüñ varın Bu benünlik seni ḥayfã yabanda ḳodı devletden

270. Koyuban diliñi hū di dil ü cān-ile yā hū di Ḳararmış ḳalbimi yu di kerem ḳıl āb-1 şefḳatden

271. Gider lag̉vı diliñ pāk it ḳo kibri sen seni ḩāk it Șuçı̃ añup yıḳañ çāk it ırılma istigāāsetden

272. Tażarruclar ḳılup yalvar it-kim yā ilāhỉ ben Huaṭā ḳıldım caṭā ḳ̣ıl sen ḩafāvetden sehāvetden 
273. Ümīd ol-dur ki șuçıñdan geçe raḥm eyleyüp Raḥmān

Mucazzez ḳıla mahşserde macārifle muhānetden

274. Dilersiñ kim geçe Tañrı tecālā seyyi'ātıñdan

Ṭut emrini habibine olñur gerçek ümmetden (17-b)

\section{SONUÇ}

Türk edebiyatında müstakil manada yazılan nasîhat-nâmelerin yanında bir kitabın parçası durumunda olan birçok nasîhat-nâme mevcuttur. Ele aldığımız Kasîde-i Şinâsi başlıklı nasîhat-nâme de bunlardan biri olup İman Manzumesi adlı eserin baş kısmında bulunan manzum bir nasîhat-nâmedir.

İman Manzumesi adlı eser seksen varaktan oluşmaktadır. Eserin kime ait olduğu belirtilmemiştir. Eserde Kasîde-i Şinâsi başlıklı manzum nasîhat-nâmeyle birlikte toplam beş başlık vardır. Eserin tamamlandığı kısımda bulunan hicri 1063 (m. 1652/1653) tarihinin istinsah tarihi olduğu anlaşılmktadır. Risâle-i Kadı-zâde Efendi Rahmetullahi Aleyh başlıklı bölümdeki bir beyitte risale yazarı Nakşibendi olduğunu ifade etmektedir. 17. yüzyılda yaşamış önemli bir şahsiyet olan Kadızâde Mehmed Efendi (ö. 1635), Risâle-i Müdâfa'a adlı eserinde Nakşibendi tarikatına mensup olduğunu belirtir. Ayrıca eserlerinde isim kullanmayı tercih etmez. Nakşilikle ilgili bilgiler, eserlerde isim kulanmanın tercih edilmemesi, Kadızâde Mehmed Efendi'ye ait olduğu tespit edilen diğer eserlerdeki bilgilerle bu eserdeki bilgilerin içerik bakımından benzerliği ve "Haza Risâle-i Kadı-zâde Rahmetullahi Aleyh" ile "Risâle-i Kadızâde Efendi Rahmetullahi Aleyh" bölüm başlıklarında geçen "Kadıâde" lakabından dolayı Iman Manzumesi'nin Kadıâde Mehmed Efendi'ye ait olması kuvvetle muhtemeledir. Eser Kadızâde Mehmet Efendi'nin ölümünden sonra Kasîde-i Şinâsi başlıklı nasîhat-nâme eklenerek istinsah edilmiştir.

Kasîde-i Şinasî' de mahlas beyti bulunmamaktadır. Ancak başlıkta Şinâsi mahlasının kullanılması nasîhat-nâmenin Şinâsi mahlaslı biri tarafından yazıldığını ortaya koymaktadır. Kaynaklarda Şinâsi mahlaslı kişilerle ilgili olarak 17. yüzyılda yaşamış olan Abdurrahman Şinâsi Çelebi (ö. 1675) ve Ruznâmeci-zâde Şinâsi'nin (ö. 1702/1703) isimleri geçmektedir. Ruznâmeci-zâde Şinâsi divan sahibi olup divanı üzerine iki tez çalışması yapılmıştır. İki çalışmada da böyle bir nasîhat-nâme mevcut değildir. Abdurrahman Şinâsi Çelebi Rumelili olup kadılık ve müderrislik yapmış bir şahsiyetir. Sicill-i Osmanĩ de şair olduğu belirtilir. Nasîhat-nâmede kullanılan Arapça kelimelerin fazlalığı ve bu kelimelerle ilgili türetmeler şairin iyi bir Arapça eğitimi aldığını göstermektedir. Abdurrahman Şinâsi Çelebi'nin kadılık yapmak için iyi bir eğitim almış olması gerektiği düşünüldüğünde nasîhat-nâmenin ona ait olması ihtimali güçlenmektedir. Onun ölüm tarihi ile eserin istinsah tarihi biribirine yakındır. Rumelili olduğundan dolayı Kadızâde Mehmed Efendi'nin yaşamış olduğu İstanbul'a temas etmiş olması ihtimali oldukça yüksektir. Nasîhat-nâmenin son beyitlerinde kadılık yaptığına dair izler de mevcuttur. Ayrıca nasîhat-nâmenin müellifi Şinâsi ile kitabın müstensihinin aynı kişi olması ihtimali kuvvetlidir. 
Şinâsi İslam dininin kurallarına sıkı bir şekilde bağlıdır. Dinin ibadetle ilgili hususlarının eksiksiz bir şekilde yerine getirilmesi gerektiğini savunur. Özellikle namaza ve namazın cemaatle eda edilmesine vurgu yapar. Ona göre tefekkürde olunmalı ve varoluş sebepleri sorgulanmalıdır. Cennet ve cehennem üzerinden ceza ve ödül faktörlerini sık sık kullanarak söylediklerini etkili kılmaya çalışır. Şinâsi'ye göre cennet her türlü zevkin, cehhennem ise şiddetli acıların bulunduğu bir yerdir. "Şerìcat cevşenin giyin tarikat cübbesin pâyın" diyerek şeriatin ve tarikatın birlikte yol alması gerektiğini belirtir. Nasîhat-nâmede sürekli vaaz havasında ve gür bir tonda seslenmeler görülmektedir. Bu, kişinin günlük hayatında edinmiş olduğu bir alışkanlığın esere sirayet etmesi şeklinde açıklanabilir. Buna dayalı olarak Abdurrahman Şinâsi Çelebi'nin, kadılık mesleğiyle ilgili tavırlarını esere yansıtmış olduğu söylenebilir.

Manzum nasîhat-nâmelerde genelde mesnevi nazım şekli kullanılır. Bu nasîhatnâmede kaside nazım şekli görülür. Kaside aruzun uzun kalıplarının kullanılmasına elverişlidir. Eserde (mefācīilün / mefāāilün / mefācīiün / mefācīiün) kalıbı mevcuttur. Kalıp şairin daha fazla sözcügü ve çok heceli sözcükleri kullanmasına imkân sağlar. Özellikle kafiye oluşturan sözcüklerin dört heceli olması dikkat çekicidir. Çok sözcük kullanımı konunun daha yoğun olarak ele alınmasına fırsat verir. Nasîhat-nâme 274 beyitten oluşmaktadır. Kaside geleneğine göre beyit sayısı fazladır. Nasîhat-nâmede iç içe geçmiş olan konuların kaside formatına göre bölümlere ayrılması durumu söz konusu değildir. Eserde eski Anadolu Türkçesinin dil özellikleri görülür. "Yeyni, esriklik ve dürişmek" gibi eskicil Türkçe kelimelerin kullanımı mevcuttur.

\section{EXTENDED ABSTRACT}

There are many nasîhat-nâmes in Turkish literature. These are mixed works some of them are verse-prose, some of them are verse, some of them are prose. Some of the nasîhat-nâmes are separate, and some are parts of the work.

The basis of nasîhat-nâme, which contains moral, religious, social and didactic messages, goes back to the Orkhun Monuments. The number of works of this type increases after the adoption of Islam by the Turks. Generally, religious-mystical advices are seen.

Social, economic and military problems that started in the 16th century and continued in the 17th century are observed in the Ottoman Empire. The murder of Osman II. and the enthronement of Mustafa I., who is mentally unstable, aggravates these troubles. Prolonged wars and social disorder drive the people into dismay. In this period, in addition to the politics written in order to relieve people who are overwhelmed by social troubles and to increase their dependence on the religion of Islam. Kasîde-i Şinâsi is one of the nasîhat-nâmes written for his purpose.

Kasîde-i Şinâsi is located at the beginning of the work named Iman Manzumesi in the Manuscript Library of the Directorate of Religious Affairs. There is no information about who the Iman Manzumesi belongs to. The fact that the writer of the treatises stated that he was a member of the Naqshbandi order and generally did not prefer to use names indicates that the owner of the work was Kadızâde Mehmed Efendi. His 
death date is 1635 . The copying date of the work is 1652 or 1653 . The work was copied after the death of Kadizâde Mehmed Efendi. The Kasîde-i Şinâsi in this work is also thought to belong to Abdurrahman Şinâsi Çelebi.

There is no information regarding to whom Kasîde-i Şinâsi belongs. However, based on the name Şinâsi, it is thought that the work belongs to someone named Şinâsi or a poet using this pseudonym. Looking at the poets with the pen name Şinâsi who lived in the 17th century in the sources, it is estimated that this advice belongs to Abdurrahman Şinâsi Çelebi. The fact that the poet has a command of Arabic because of his profession as a judge and reflects this on the work, using a language in the atmosphere of preaching makes this possibility stronger.

Kaside-i Şinâsi is a work written to give religious, moral and mytical advice. The work mentions the importance of prayer, the fact that the world is a temporary place, that one has to search and question oneself and the characteristics of heaven and hell. Şinâsi made use of verses, hadiths, idioms and proverbs to make what he said effective.

Nasîhat-nâme consists of 274 couplets. It is written with the mold of aruz (mefâcīün / mefấilün / mefấilün / mefâcḷlün). The words that make up the rhyme in the work in which the full rhyme is used are generally words of Arabic origin. These words usually consists of four syllables. Language features of old Anatolian Turkish can be seen in the work. Old Turkish words such as "esriklik, yeyni and dürişmek" are available in the work. 


\section{KAYNAKÇA}

Ak, M. (2018). Osmanlı'nın son döneminde manzum bir nasihatnâme: maksûd-ı nasihat (inceleme-metintıpkıbasım-dizin). Konya: Çizgi Kitabevi.

Akbayar, N. (1996). Mehmed Süreyyâ sicill-i osmânî. İstanbul: Tarih Vakfı Yurt Yaınları.

Akpınar, Ş. (2000). Ruznâmeci-zâde Şinâsi, hayatı, eserleri, edebi kişliği ve divanının tenkitli metni (Yüksek lisans tezi). Erişim adresi: https://tez.yok.gov.tr/UlusalTezMerkezi/tezSorguSonucYeni.jsp.

Aksoy, H. (1998). Derviş Şemseddin, kuşların münazarası-deh murg. İstanbul: Marmara Üniversitesi İlahiyat Fakültesi Yayınları.

Altun, K. (1997). Tezkire-i Mucib inceleme-tenkidli metin-dizin-sözlük. Ankara: AKM Yayınları.

Arslan, M. (1994). Pend-nâme-i Zarîfî. Sivas: Dilek Matbaacilık.

Arslanoğlu, İ. (1992). Şah İsmail Hatayî ve anadolu hatayîleri. İstanbul: Der Yayınları.

Askerî. Pend-nâme-i Askerî. Süleymaniye Kütüphanesi. Ali Nihat Tarlan Koleksiyonu, 62/2.

Ay, K. (2018). Bir Nasihatnâme Örneği Olarak Ali B. Mahmud'un Umûr-ı Ahvâl-i Sefer Adlı Eseri: Tahlil ve Metin (Yüksek lisans tezi). Erişim adresi: https://tez.yok.gov.tr/UlusalTezMerkezi/tezSorguSonucYeni.jsp.

Babinger, F. (1982). Osmanlı tarih yazarları ve eserleri, (C. Üçok, Çev.). Ankara: Kültür ve Turizm Bakanlığı Yayınları.

Belen, M. (1997). Hızrî'nin âb-ı hayât mesnevisi (inceleme-metin). (Yüksek Lisans Tezi). Erişim adresi: https://tez.yok.gov.tr/UlusalTezMerkezi/tezSorguSonucYeni.jsp.

Benli, Ş. (2020). Dört dörtlük öğütler: dört sayısı üzerine kurulmuş türkçe mensur nasihatnamelerin mukayesesi ve Kâtip Ali Efendi'nin pendnâme'si. Akademik Dil ve Edebiyat Dergisi, 4(4), 10691092. doi: 10.34083 /akaded.829135.

Beyzadeoğlu, S. A. (1996). Sünbül-zâde Vehbî - lutfiyye. İstanbul: Bedir Yayınları.

Buhârî. (2018). el-Câmi 'u's-Sahîh. $\quad$ (C. 1$). \quad$ Erişim https://ekutuphane.diyanet.gov.tr/details?id=107262\&materialType=KT\&query=el-

C\%C3\%A2mi\%CA\%BFu\%E2\%80\%99s-sah\%C3\%AEh

Bursalı Mehmet Tahir (1325). Ahlak kitaplarımız, İstanbul: Necm-i İstikbal Matbaası.

Bütün, M. (2019). ), Sarı Abdullah Efendi, nasîhatü'l-mülûk terğ̂̌bün li-hüsni's-sülûk (1b-109b): incelememetin-sözlük-dizin (Yüksek lisans tezi). Erişim adresi: https://tez.yok.gov.tr/UlusalTezMerkezi/tezSorguSonucYeni.jsp.

Cemâlî. Nasihat-nâme. Süleymaniye Kütüphanesi. Reşit Efendi Koleksiyonu, 593/5, 62a-66b.

Ceyhan, A. (2020). Harputlu Ömer Naîmî̀nin islâmî bilgi ve öğüt veren bir nasihatnamesi: manzûme-i naîmiyye. Eski Türk Edebiyatı Araştırmaları Dergisi, 3(2), 381-486. Erişim adresi: https://dergipark.org.tr/tr/pub/estad/issue/56598/778182.

Çağrıcı, M. (2006). Nush. İslâm ansiklopedisi. (C. 32, s. 408-409). Ankara: Türkiye Diyanet Vakfı Yayınları.

Çelebioğlu, A. (1999). Türk edebiyatı'nda mesnevi (XV. yy. 'a kadar). İstanbul: Kitabevi Yayınları.

Çelik, A. (2018). Kâinata hikmet nazarıyla bakmak: ma'ârif-nâme'de lisân-1 hâl örnekleri. HikmetAkademik Edebiyat Dergisi, Prof. Dr. Ali Nihad Tarlan Özel Sayıs1, 560-580. doi: 10.28981/hikmet.498434.

Çınar, B. (2014). Mantıkî'nin nasihatnâme'si, TÜBAR, XXXV, 85-98. doi: 10.17133/tba.81504

Diyanet İşleri Başkanlığı (t.y.). Kur'an-ı Kerim. https://kuran.diyanet.gov.tr/mushaf/kuran-meal2/fatiha-suresi-1/ayet-1/diyanet-isleri-baskanligi-meali-1. Erişim tarihi: 05.02.2021.

Durmuş, A. (2020). Kadızâde Mehmed Efendi'nin bilinmeyen risalesi risale-i müdâfa'a ışığında hayatı ve ilmi kişiliği -tercüme tahkik ve değerlendirme-. Tokat İlmiyat Dergisi, 8(1), 321-350. doi: 10.5281/zenodo.3894609.

Ebû Davûd, (2009). Sünenü Eb̂̂ Dâvûd. (C. 7). Erişim adresi: https://ekutuphane.diyanet.gov.tr/details?id=89346\&materialType=KT\&query=S\%C3\%BCley man+b.+E\%C5\%9F\%27as+b.+\%C4\%B0shak+b.+el-Ezdi+Eb\%C3\%BB+Davud+es-Sicistani.

Emîrî. Gülşen-i Ebrâr. Nuruosmaniye Kütüphanesi, T. y., 2584/1. 
Fazlî. Pend-nâme-i Fazlî. Süleymaniye Kütüphanesi. Esat Efendi Koleksiyonu, 245/2.

Harmancı, E. (1999). Şinasî Divanı (Yüksek lisans tezi). Erişim adresi: https://tez.yok.gov.tr/UlusalTezMerkezi/tezSorguSonucYeni.jsp.

Hengirmen, M. (1983). Pend-nâme. Ankara: Kültür ve Turizm Bakanlığı Yayınları.

Hüseynî. Camiü'n-Nasâyih. Süleymaniye Kütüphanesi. Hacı Beşir Ağa Koleksiyonu, 661/19.

İbn-i Mâce, (2009). Es-Sünen. (C. 5). Erişim https:/ekutuphane.diyanet.gov.tr/details?id=89393\&materialType=KT\&query=+\%C4\%B0bn+ $\mathrm{M} \% \mathrm{C} 3 \% \mathrm{~A} 2 \mathrm{ce}$.

İbrahim Gülşenî, Pend-nâme-i. Süleymaniye Kütüphanesi. Mahmud Efendi Koleksiyonu, 1042/3, 17b20a.

İlmî. Pâdişaha Nasihat Yollu Manzûme, Topkapı Sarayı Müzesi Kütüphanesi, E. H. 968, 125a.

İmâm-1 Rabbânî. (2019). Mektûbât-2-3, İstanbul: Fazilet Neşriyat.

İslamoğlu, A. (2012). Halil Efendi'nin lübbü'n-nesâyıh adlı eserinin şekil ve muhteva özellikleri. Sakarya Üniversitesi Ilahiyat Fakültesi Dergisi, XIV/26, 119-148. Erişim adresi: https://dergipark.org.tr/tr/pub/sakaifd/issue/20620/219783.

Kaplan, M. (1992). Divan edebiyatında manzum nasihat-nâme yazan şairler ve eserleri I. Yüzüncü Yıl Üniversitesi Fen Edebiyat Fakültesi Sosyal Bilimler Dergisi, 3/3, 23-68.

Kaplan, M. (1993a). Şeyh Cemal-ı Karaman̂̀'nin nasihat-nâmesi. Erişim adresi: https://www.altayli.net/turk-edebiyatinda-manzum-nasihat-nameler.html.

Kaplan, M. (1993b). Gubarî Abdurrahman Efendi'nin pend-nâmesi. Erişim adresi: https://www.altayli.net/turk-edebiyatinda-manzum-nasihat-nameler.html.

Kaplan, M. (1993c). Ankaralı Nidâ̂̀'nin manzum tıbb̂̂ nasihat-nâmesi. Erişim adresi: https://www.altayli.net/turk-edebiyatinda-manzum-nasihat-nameler.html.

Kaplan, M. (1993d). Meşâmî ve pendnâmesi", İslâmî Edebiyat Dergisi, 3/22, 117-121.

Kaplan, M. (1997). Pend-nâme-i vak'a-nüvis Es‘ad Efendi. Erciyes, 236, 13-16.

Kaplan, M. (2001). Manzum Nasîhat-nâmelerde Yer Alan Konular. Selçuk Üniversitesi Türkiyat Araştırmaları Dergisi, 9, 133-185. Erişim adresi: https://dergipark.org.tr/tr/pub/sutad/issue/26292/277039.

Kaplan, M. (2015). Hayriyye-i Nâbî. Ankara: Atatürk Kültür Merkezi Yayınları.

Kaya, İ. G. (1995). Derviş Şemsi ve deh murg mesnevisi (inceleme, tenkitli metin ve tıpkıbasım). Cambridge: Harvard Üniversitesi Yakındoğu Dilleri ve Medeniyetleri Bölümü Yayınları.

Kazancıoğlu, H. (2019). 17. yüzyıl mutasavvıflarından kâdirî Muhyiddîn'in nasîhatnâmesinde osmnalı devlet işleyişi ve sosyal hayat. İslam Medeniyeti Araştırmaları Dergisi, 4(1), 32-67. doi: 10.20486/imad.532924.

Kılıç, A. (2005). Müridî ve Pend-i Ricâl adlı mesnevisi (inceleme - tenkitli metin - dizin). İzmir: Akademi Kitabevi.

Koşik, H. S. (2012). Nasîhatnâme-i Sıdkî [inceleme-metin] (Yüksek lisans tezi). Erişim adresi: https://tez.yok.gov.tr/UlusalTezMerkezi/tezSorguSonucYeni.jsp.

Köprülü, F. (2014). Türk edebiyatı tarihi. İstanbul: Alfa Yayıncılık.

Kurnaz, F. (2018). Nasuh Nevâlî'nin çeşme-i hayat adlı nasihatnâmesi inceleme-metin-sözlük (Yüksek lisans tezi). Erişim adresi: https://tez.yok.gov.tr/UlusalTezMerkezi/tezSorguSonucYeni.jsp.

Kurt, H. (2020). XVI. yüzyıl şairlerinden Hakkânî'nin cevâhir adlı mesnevisi, Akademik Dil ve Edebiyat Dergisi, 4/2, 486-547. https://doi.org/10.34083/akaded.746401.

Levend, A. S. (1963). Ümmet çağında ahlâk kitaplarımız. Türk Dili Araştırmaları Yılliğı - Belleten, 11, 89-115.

Mansuroğlu, M. (1956). Ahmed Fakih-çarhnâme. İstanbul: İstanbul Üniversitesi Edebiyat Fakültesi Yayınları.

Mürşid Efendi. Pend-i Mürşidî, Milli Kütüphane, A. 784.

Oğuz, M. Ö. (1990). Yozgatlı Hüznî divanlarından seçmeler. Ankara: Feryal Matbaacılık. 
Özkan, M. (2016). Osmanlı'da ilmihal geleneği: Kadızâde Mehmed Efendi (1045/1635) ve "risale-i kadızâde" adlı çalışması, İslam Hukuku Araştırmaları Dergisi, 27, 553-574. Erişim adresi: http://www.islamhukuku.com/Default.aspx.

Pala, İ. (2006). Nasihatnâme. İslâm Ansiklopedisi. (C. 32, s. 409-410). Ankara: Türkiye Diyanet Vakfı Yayınları.

Rızaî. Nazmu'l-Ulûm, Milli Kütüphane. A. 2433/(96b-109a).

Sâfî. Gülşen-i Pend. Konya Yusufağa Kütüphanesi, T. y. 8471.

Saruhanlı Gülşenî. Dil-Güşâ. Süleymaniye Kütüphanesi. Esat Efendi Koleksiyonu, 1403.

Selçuk, B. (2020, 25 Kasım). Şinâsî, Abdurrahman Şinasî Çelebi. Erşim adresi: http://teis.yesevi.edu.tr/madde-detay/sinasi-abdurrahman-sinasi-celebi.

Sevindik, H. (2010). Fasîh Ahmed Dede'nin behişt-âbâd mesnevisi. Selçuk Üniversitesi Edebiyat Fakültesi Dergisi, 23, 37-46. Erişim adresi: https://dergipark.org.tr/tr/pub/sefad/issue/16462/171757.

Söylemez, H. (2020). Hüsrev-zâde Ömer Sabrî’nin nasîhat-nâmesi [metin-inceleme] (Yüksek lisans tezi). Erişim adresi: https://tez.yok.gov.tr/UlusalTezMerkezi/tezSorguSonucYeni.jsp.

Tatcı, M. (2005). Risâletü'n-Nushiyye - tenkitli metin. İstanbul: Milli Eğitim Bakanlığı Yayınları.

Tınç, S. (1996). Arif hayatı, eserleri, edeb̂̂ kişiliği ve eserlerinin tenkitli metni. (Yayınlanmamış Doktora Tezi). Selçuk Üniversitesi, Konya.

Tirmizî, (2019). Sünenü't-Tirmizî. $\quad$ (C. 1$)$ Erişim https://ekutuphane.diyanet.gov.tr/details?id=89609\&materialType=KT\&query=Tirmizi.

Üveysî. Nasihat Yollu Manzûme. Milli Kütüphane A. 4635.

Veled Çelebi \& Kilisli Muallim Rıfat (1340/1922). Ferheng-nâme-i Sa'dî̀, İstanbul: Matbaa-i Amire.

Yalçınkaya, M. A. (2019). 16. yüzyıla ait mensur bir nasihatnâme: Za'îfî'nin kitâb-1 sabru'l-mesâyib'i. Akademik Dil ve Edebiyat Dergisi, 3/1, 104-119. doi: 10.34083/akaded.547388.

Yavuz, K. (2000). Âşık Paşa, garib-nâme (I-II). Ankara: Türk Dil Kurumu Yayınları.

Yeniterzi, E. (2006). Ahmed-i Dâ'î'nin vasiyyet-i nûşirevân adlı mesnevisi. Türkiyat Araştırmaları Dergisi, 19, 1-25. Erişim adresi: https://dergipark.org.tr/tr/pub/sutad/issue/26277/276850.

Yetîmî. İbret-nâme. Süleymaniye Kütüphanesi. İbrahim Efendi Koleksiyonu, 588/1.

Yiğit, B. K. (2015). Süleyman Penâhî’nin nasihatnamesi. Gazi Üniversitesi Sosyal Bilimler Dergisi, 2/3, 105-141. Erişim adresi: https://arastirmax.com/sites/default/files/filefield_paths/c2s3m7.pdf.

Yiğit, M. (1986). Refi'̂̀'nin beşâret-nâme'si dilbilgisi, karşılaştırmalı metin, sözlük. (Yayınlanmamış Doktora Tezi). Yüzüncü Yıl Üniversitesi, Van.

Yiğiterol, Ö. F. (2019). 18. yüzyılda yazılmış bir nasihat kitabı: levhnâme. İslam Medeniyeti Araştırmaları Dergisi, 4/1, 100-122. doi: 10.20486/imad.615043.

Zâifî. Bustân-ı Nesâyih, Topkapı Sarayı Kütüphanesi. Revan Koleksiyonu, 822/2. 


\section{EKLER (Yazmanın varakları)}

\section{TIPKIBASIM}

1-b/17-b
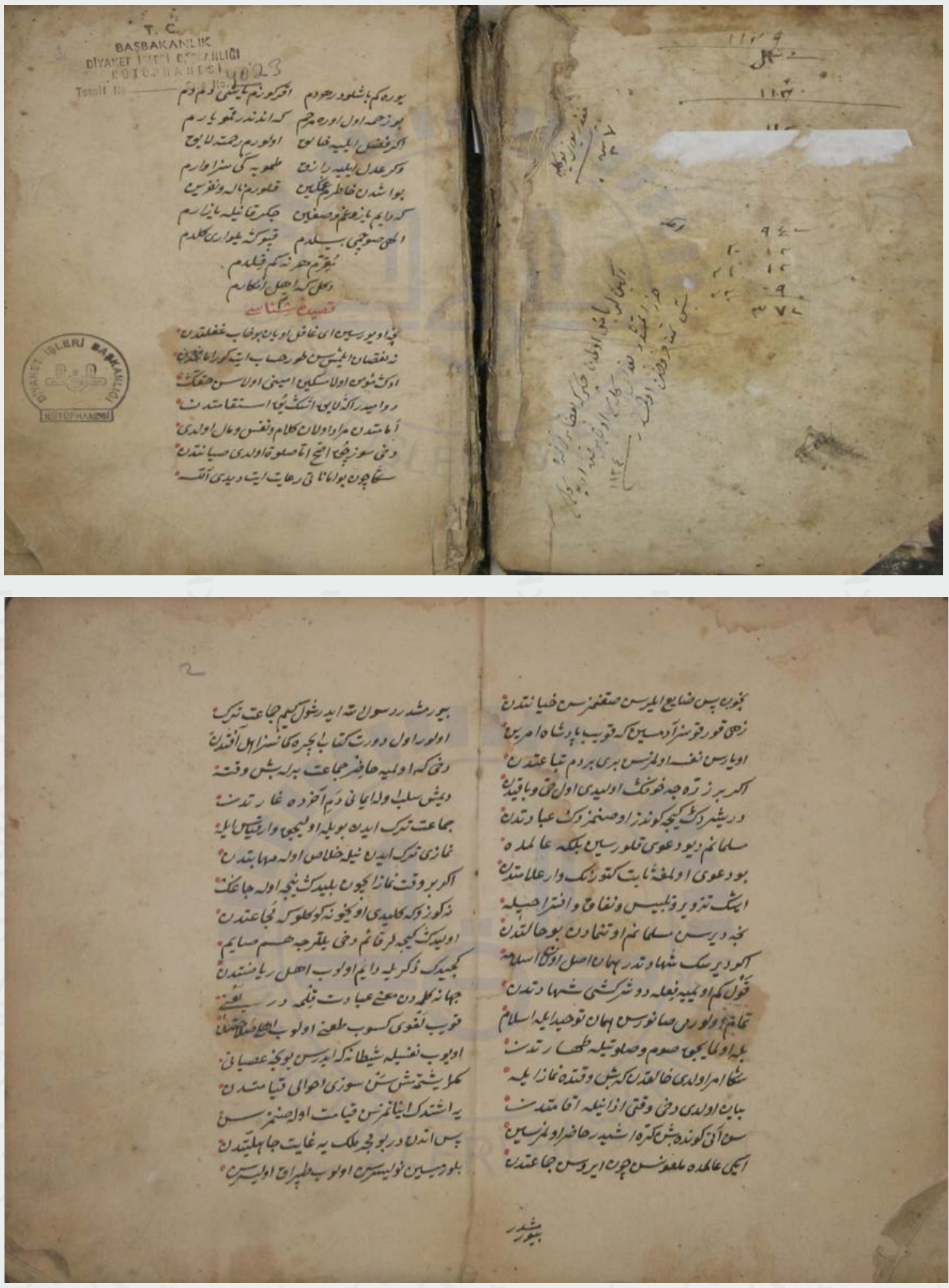

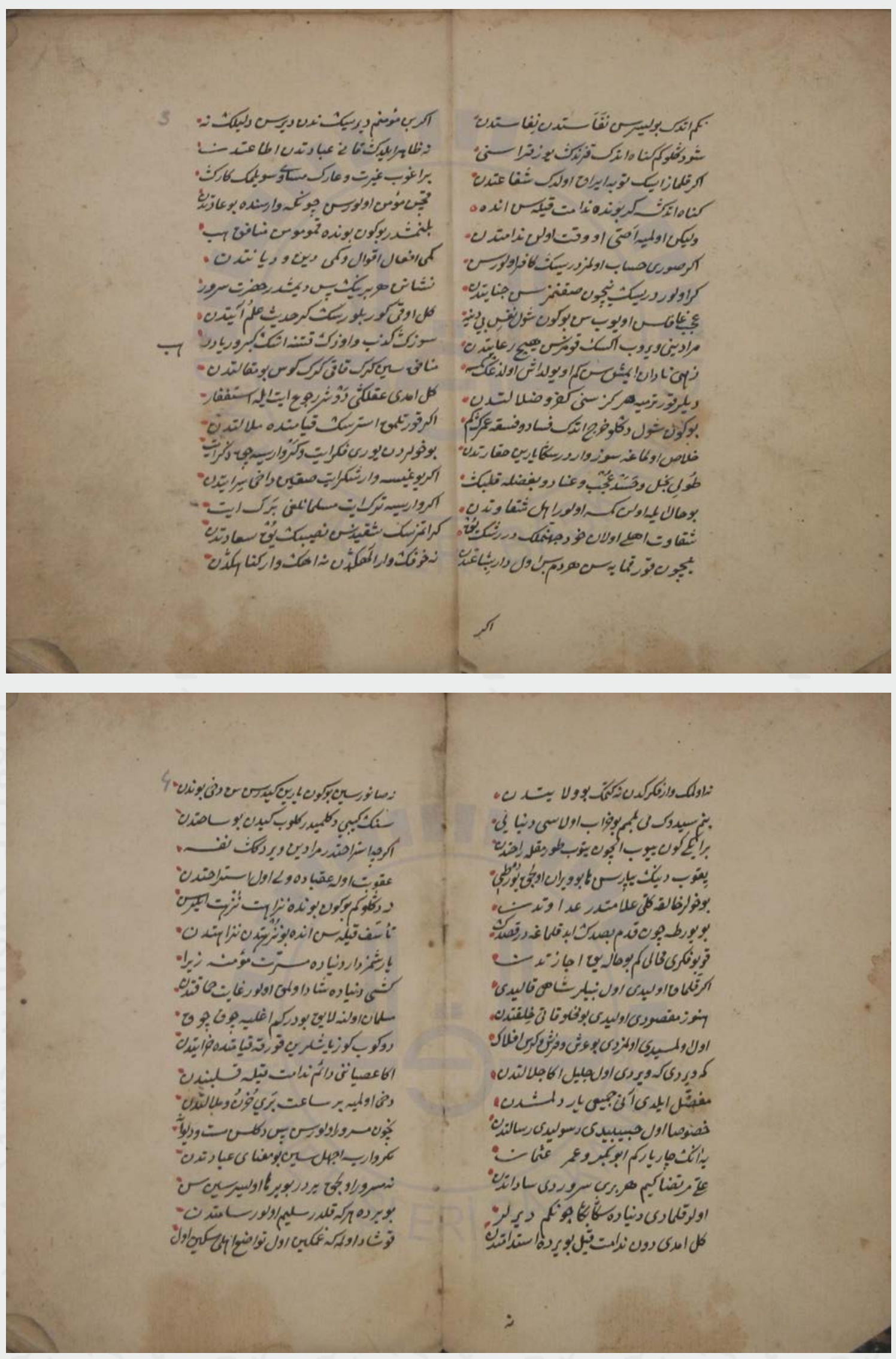

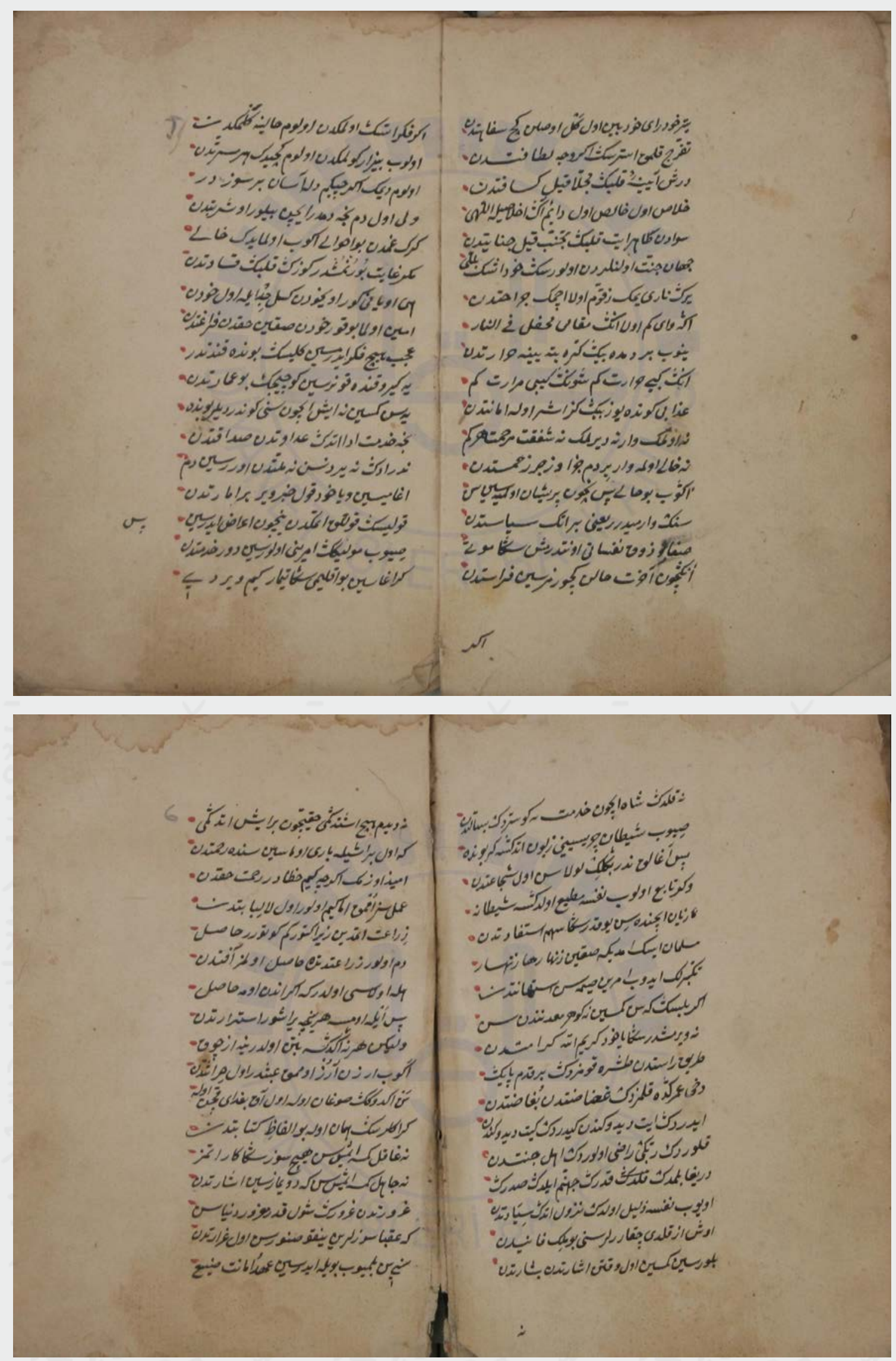


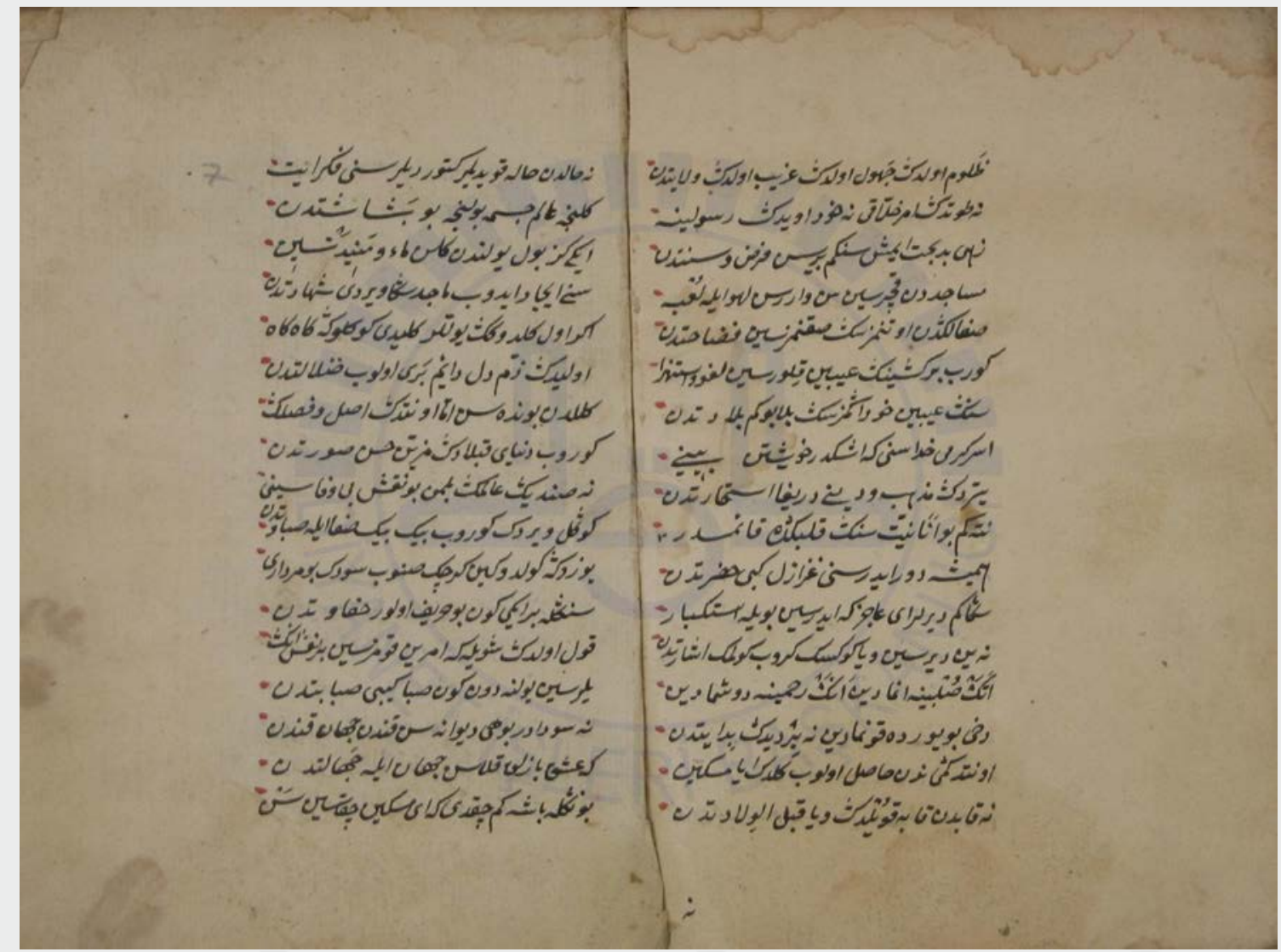

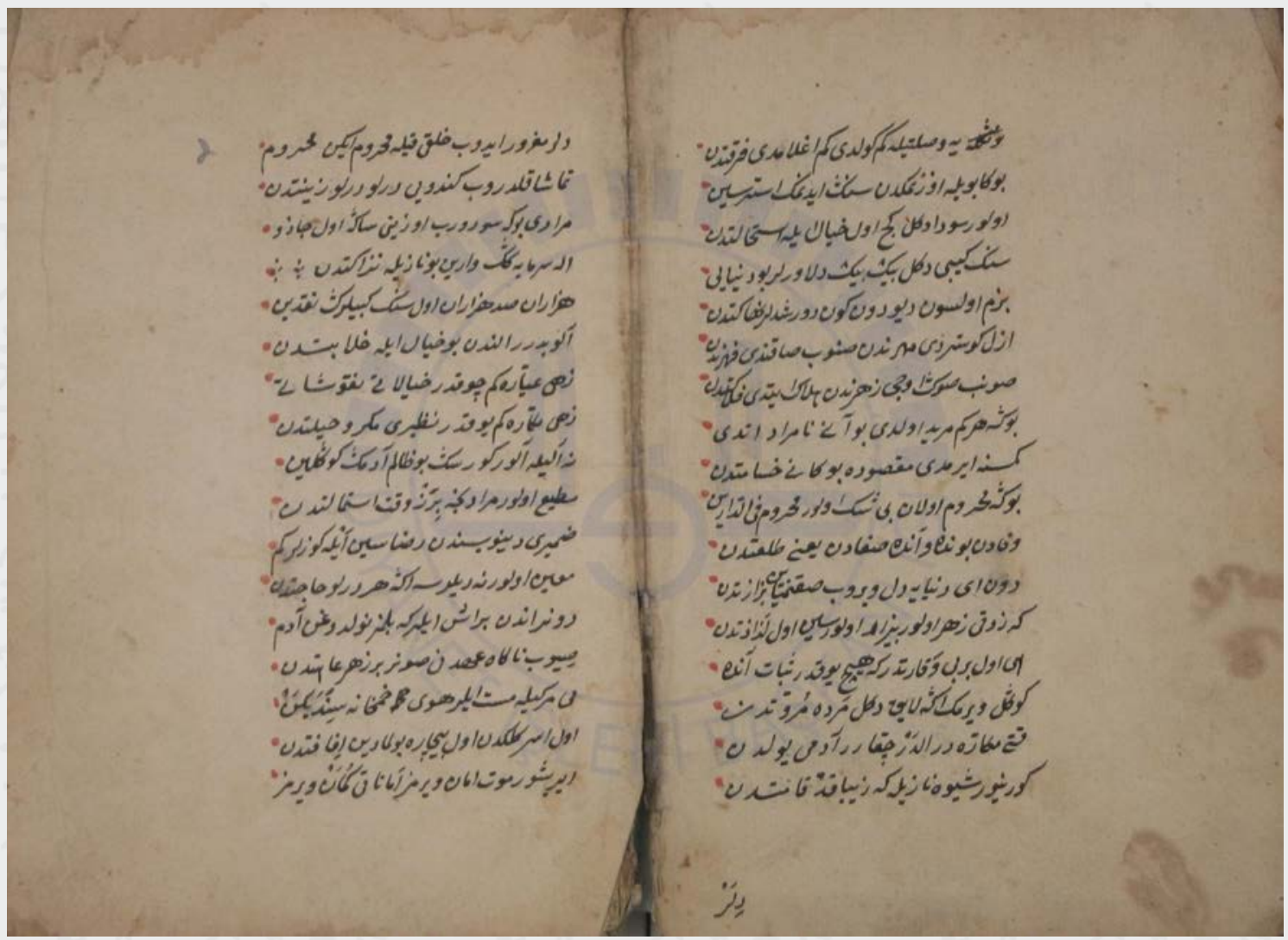



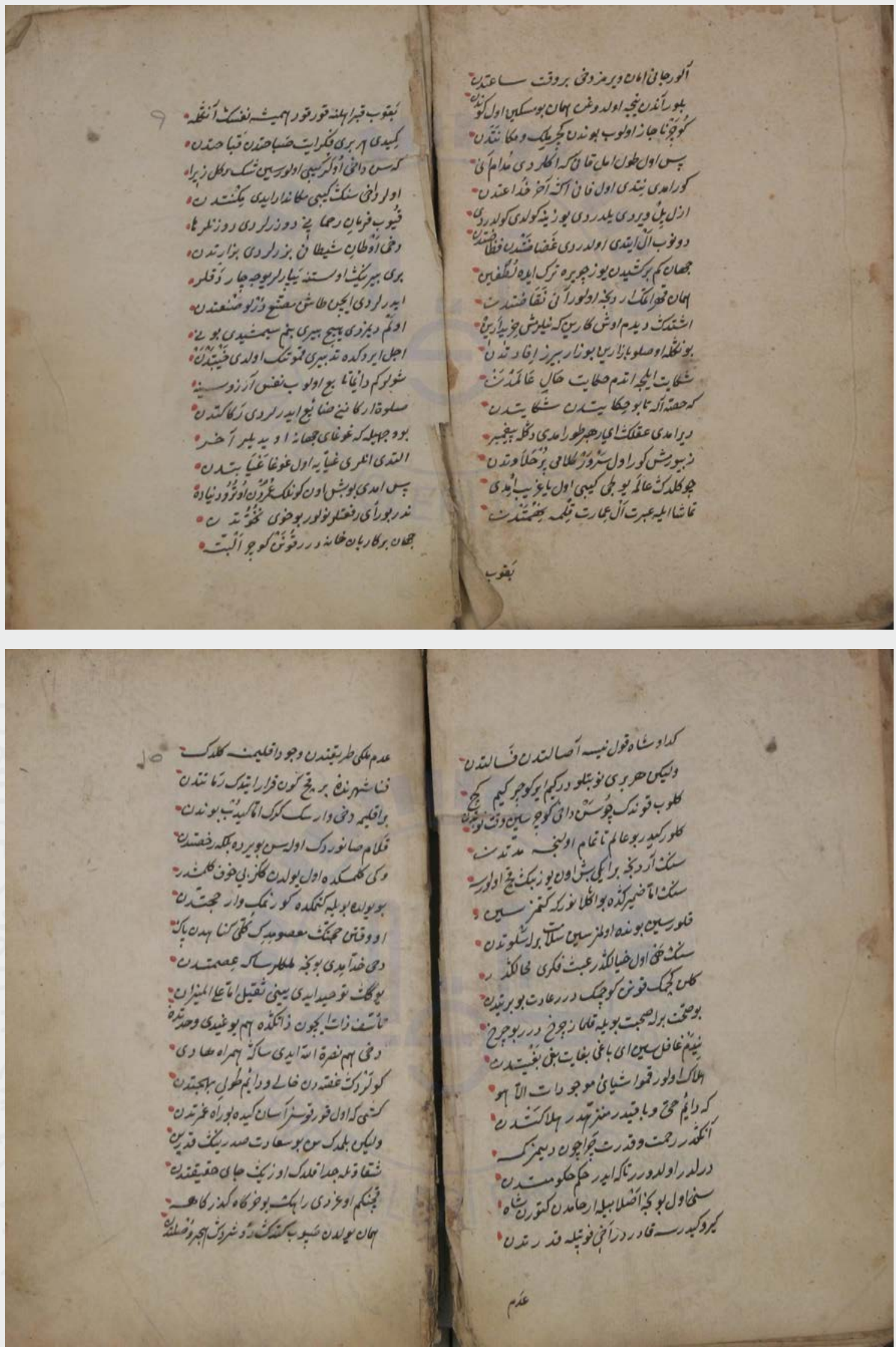

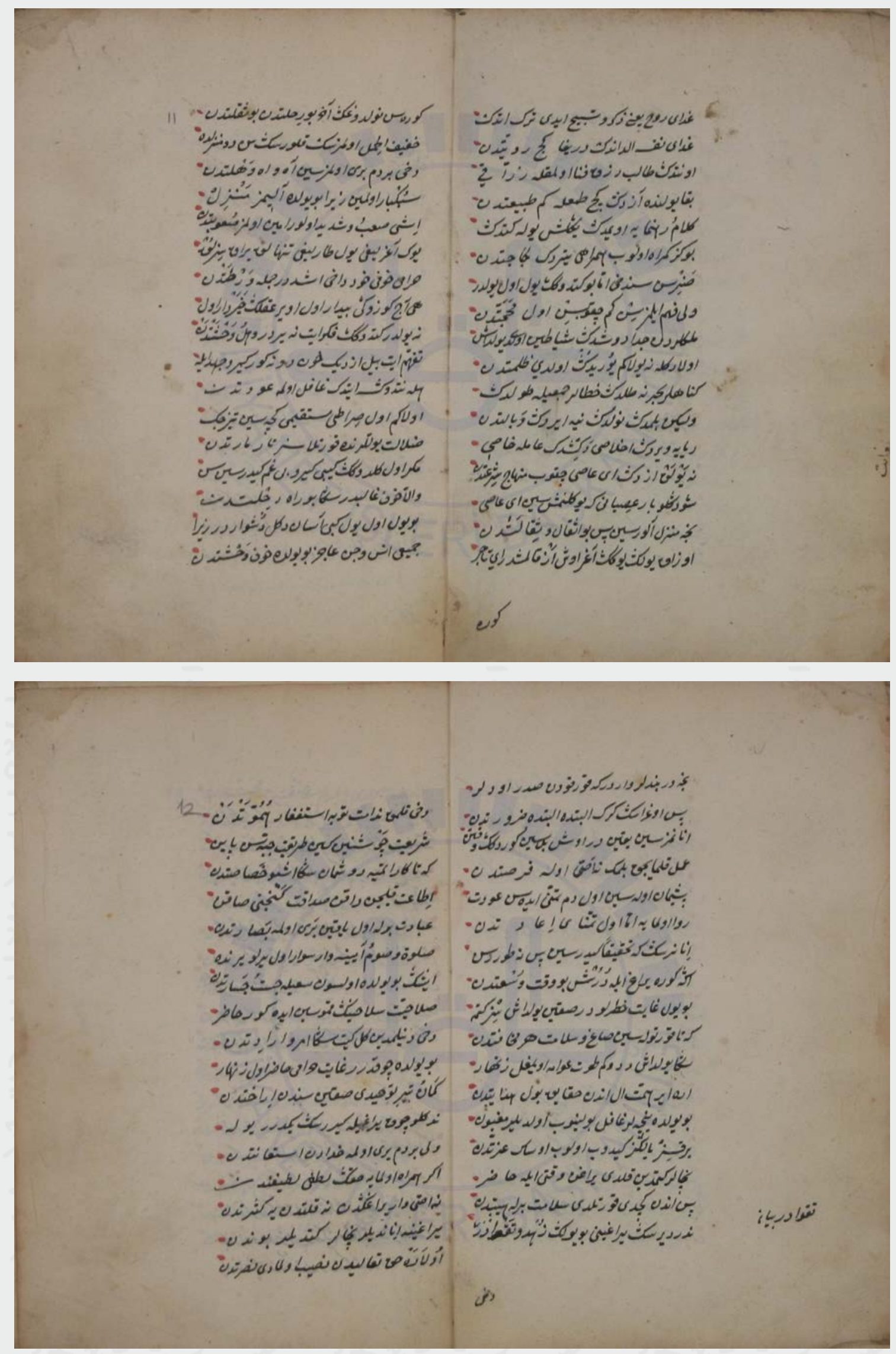

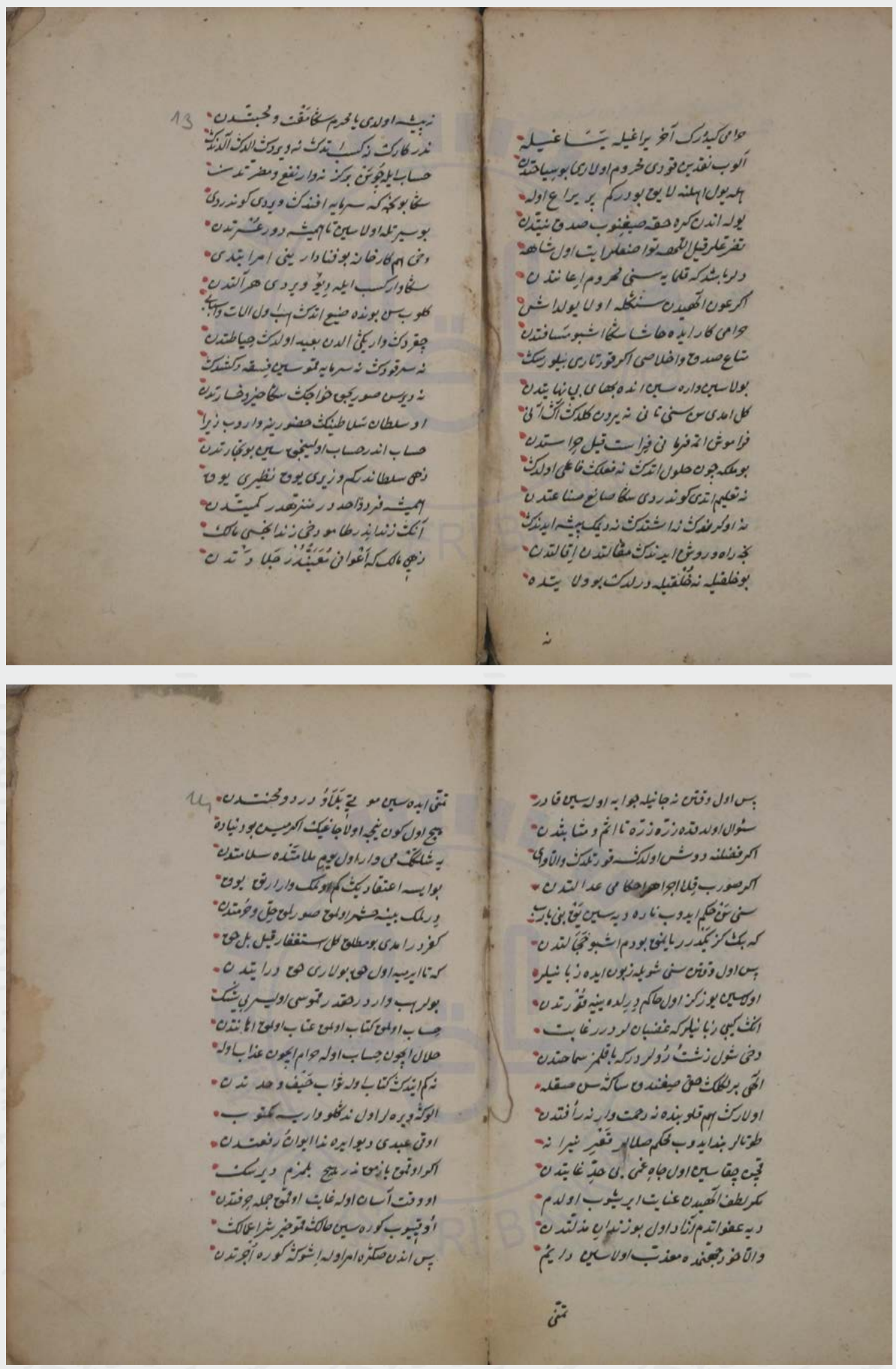


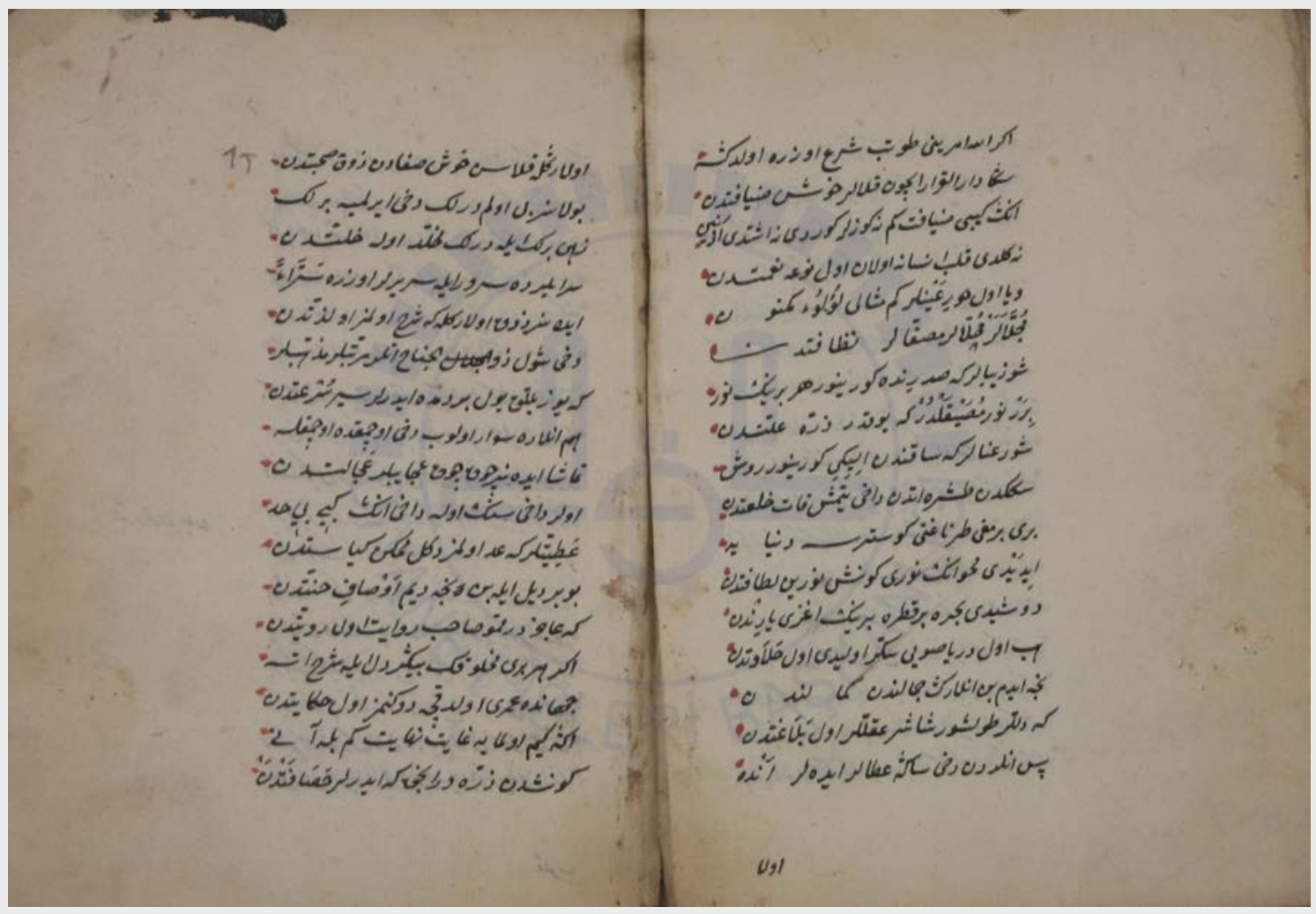

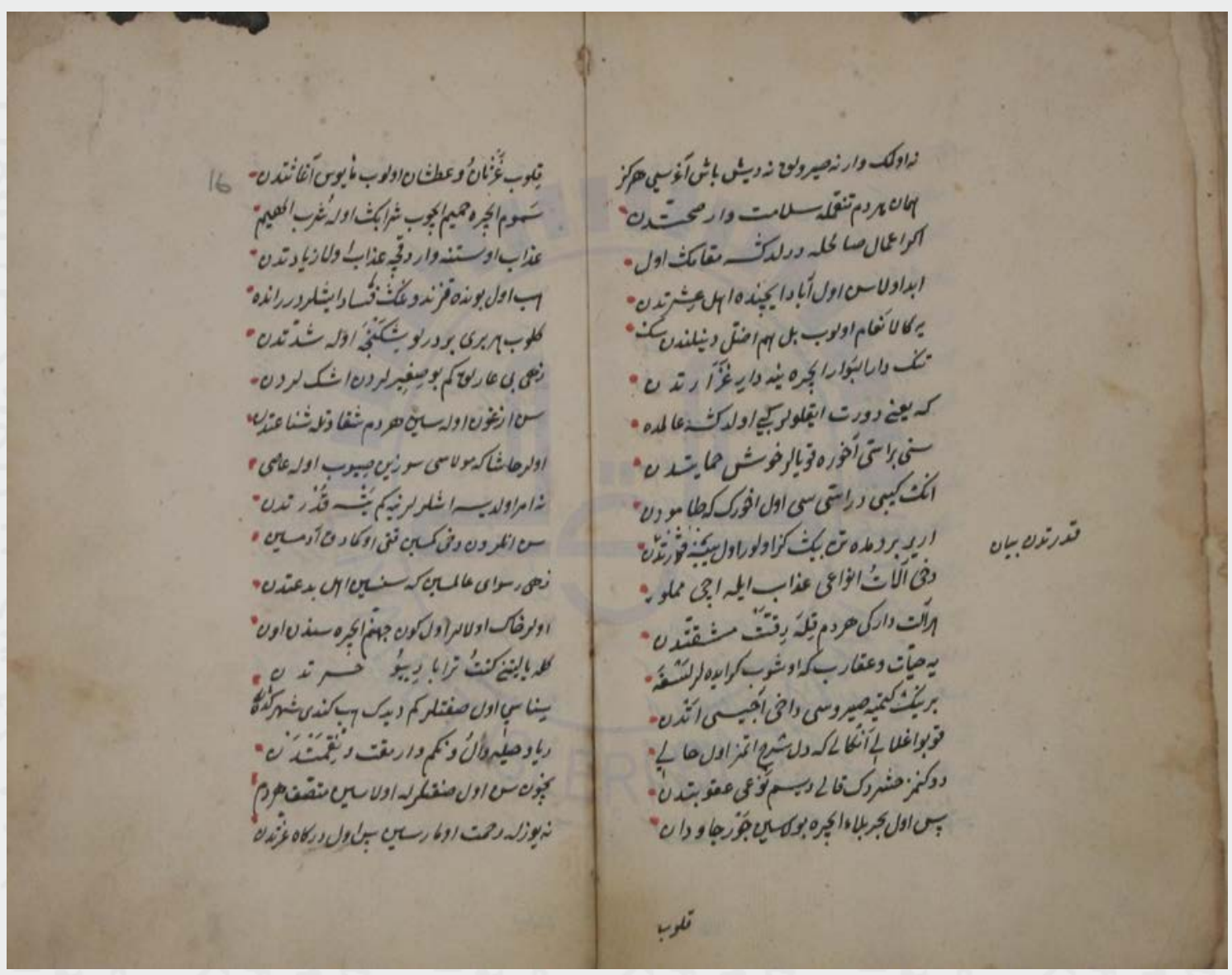




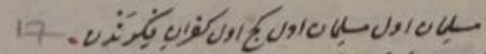

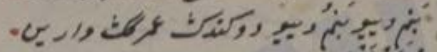

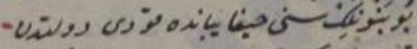

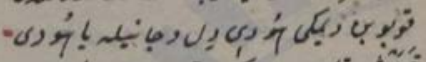

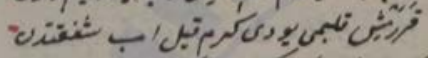

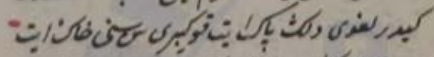

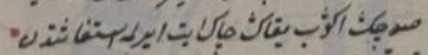

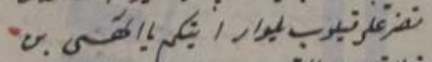
خطاقلدمعاتز

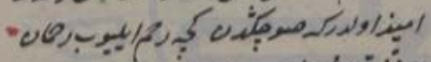

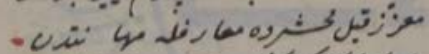

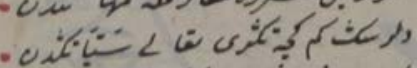

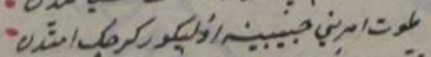

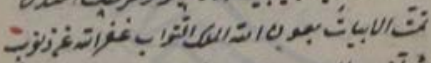
ن gP०
- تأح

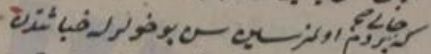

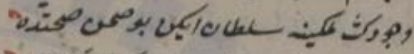

"

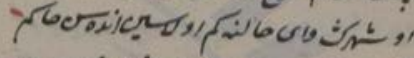

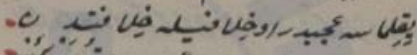

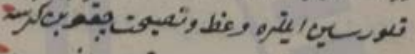

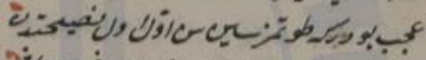

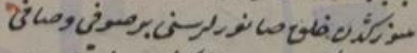

-

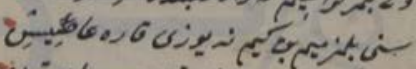

v بs

الماول

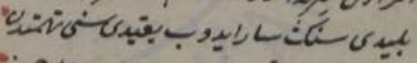

"

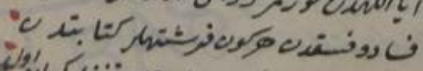

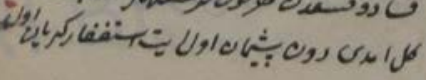

ore 